\title{
Cumhuriyet Halk Partisi İntihap Mahali Raporlarına Göre Urfa'da Siyasi, Sosyal ve Ekonomik Hayat (1944-1948)*
}

\section{Political, Social, and Economic Life in Urfa According to The Electoral Local Reports of The Republican People's Party (1944-1948)}

Selahaddin Gök, a, ${ }^{, *}$ Özlem K1lınççeker ${ }^{\text {b }}$

${ }^{a}$ Dr. Öğr. Üyesi, Adıyaman Üniversitesi, Fen-Edebiyat Fakültesi, Tarih Bölümü, Adıyaman/Türkiye. ORCID: 0000-0003-1711-9027

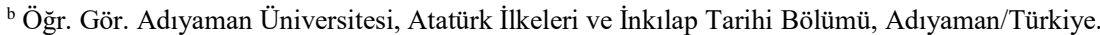
ORCID: 0000-0003-0505-3649

\section{MAKALE BİLGİSİ}

Makale Geçmişi:

Başvuru tarihi: 18 Eylül 2019

Düzeltme tarihi: 06 Şubat 2020

Kabul tarihi: 27 Şubat 2020

Anahtar Kelimeler:

Cumhuriyet Halk Partisi,

Urfa İntihap Raporları,

Siyasi Hayat ve Ekonomik Yapı

\section{A RTICLE INFO}

\section{Article history:}

Received 18 September 2020

Received in revised form 06 February 2020

Accepted 27 February 2020

\section{Keywords:}

Republican People's Party, Urfa Election District Report, Political Life and Ekonomic Structure

\section{ÖZ}

Cumhuriyet Halk Partisi Türkiye Cumhuriyetinin kuruluşunda ve şekillenmesinde etkin rol oynayan bir partidir. Bu parti 27 ylllık tek parti iktidarı süresince halkla olan etkileşimini ve kendi parti örgütünü diri tutmak amacıyla sorunları yerinde tespit ederek, çözüm üretmek için farklı mekanizmalar geliştirmiştir. $\mathrm{Bu}$ mekanizmalardan biri Cumhuriyet Halk Partisi Genel Sekreterliği'ne gönderilmek üzere her vilayet için hazırlanan raporlardır. Raporlarda parti görevlileri seçim bölgeleri ile ilgili dönemsel olarak sosyal, ekonomik, kültürel, siyasi ve idari durum hakkında gözlemlerini, tespitlerini, halkın ve bölgenin taleplerini, ihtiyaçlarını, şikâyetlerini olumlu ve olumsuz açıdan ifade etmişlerdir. Bu çalıșma 1944-1948 yılları arasında Urfa'da CHP'nin parti örgütlenmesinin ne seviyede olduğunu ve halkın yaşam koşulları ile ilgilidir. Bu araştırmada, Urfa milletvekilleri ve teşkilatı tarafından hazırlanan raporlardaki bilgiler arşiv belgeleri ışı̆̆ında ortaya konulmuştur.

\section{A B S T R A C T}

The Republican People's Party (CHP) is a party that has played an active role in the foundation and formation of the Republic of Turkey. This party, in order to keep its interaction with people and its own party organization alive during its 27 -year period of single-party government, developed various mechanisms to pinpoint problems locally and generate solutions to them.

One of these mechanisms is the reports prepared for each city to be sent to the Office of the Secretary General of the Republican People's Party. In the reports the party officials expressed their observations and evaluations about the social, economic, cultural, political, and administrative circumstances of their electoral areas and the local people's demands, needs, and complaints both positively and negatively.

This paper aims to examine the party organization of the CHP and the living conditions of the people in Urfa in the period between 1944-1948. In this respect, important information in the reports written by the Urfa members of parliament is revealed and discussed in the light of the archive documents.

\section{Giriş}

Cumhuriyetin ilk yıllarında milletvekilleri tarafindan gerçekleştirilen inceleme gezileri ve parti teşkilatları tarafindan hazırlanıp merkez gönderilen raporlar gönderildiği mahal hakkında farklı alanlarda detaylı bilgiler içermesi açısından önemlidir. Mahalden gelen bu raporlar CHP'nin Doğu ve Güneydoğu Anadolu bölgeleri gibi uzun bir süre teşkilatı bulunmayan mahaller için daha fazla önem kazanmıştır.

\footnotetext{
* Bu makale, 4-7 Ekim 2018 Şanlıurfa'da düzenlenen Uluslararası III. Piri Reis Dil-Tarih- Coğrafya Kongresinde sunulmuş çalışmanın düzenlenmiş ve genişletilmiş halidir.

** Sorumlu yazar/Corresponding author

e-posta: ozkilincceker@adiyaman.edu.tr
} 
CHP milletvekilleri tarafından seçim bölgeleri ile ilgili hazırladıkları raporlar önemli bilgiler vermektedir. Mahallin siyasi, iktisadi, idari ve kültürel durum hakkında tespitlerini, bölgenin ve halkın taleplerini, ihtiyaçlarını, şikâyetlerini olumlu ve olumsuz yönleri ile belirtmişlerdir. Bu raporlarda CHP il örgütünün yapısı ve çalışmalarının toplum tarafından yansımaları açısından da önemlidir. ${ }^{1}$

Çalışmamıza konu olan ilk rapor 1944 yılının Nisan ayının ilk üç haftasında bölge milletvekillerince gerçekleştirilen inceleme gezisi sonunda hazırlanmıştır. Rapor bu yılın ilk altı ayını kapsamakta olup denetleme gezisini yapan Urfa milletvekilleri Kazım Berker (TBMM 2010: 431)2, Esat Tekeli (TBMM 2010: 431) ${ }^{3}$ ve Suut Kemal Yetkin (Çağatay, 1981: 5-7; Kantemir, 1980: 407-413) ${ }^{4}$ tarafindan hazırlanmıştır. İnceleme raporu Urfa ili hakkında farklı alanlarda detaylı bilgiler içermekte olup, 19 Temmuz 1944 tarihinde CHP Genel Sekreterliğine sunulmuştur. Milletvekilleri yol güzergâhı olarak Diyarbakır üzerinden gelip incelemelerine Siverek, Karacadağ, Hilvan, Kısas, Bozova (Yaylak), Akçakale, Resülayn (Ceylanpınar) ve Viranşehir istikametinde gerçekleştirmişlerdir. Gezinin yapılmasındaki amaç seçim mahalleri ile ilgili durum tespiti yaparak, ortaya çıkan aksaklıkları belirlemek ve sorunları ilgililer ile parti yönetimi nezdinde çözüme kavuşturmaktır.

Raporda dile getirilen konular partinin yetkili organı olan CHP Genel Sekreterliğine sunulduktan sonra tasnifi yapılarak ilgili birimlere gönderilip, takibi yapılmıştır. Yetkili birimlerce dile getirilen konular olumlu-olumsuz değerlendirilmeye tabi tutulup durum hakkında Genel Sekreterlik bilgilendirilmiştir. CHP Genel Sekreteri Memduh Şevket Esendal 7 Haziran 1945 tarih ve 2/77861 sayı ile Urfa milletvekillerine gönderdiği yazıda seçim yerlerinde yapmış oldukları gezi ve incelemeye ait ortak raporda dile getirilen hususların yetkili makamlar nezdinde takip edildiği vurgulanmıştır. Ayrıca raporda belirtilen hususlarda neler yapıldığı konusunda ilgili birimlerden verilen cevaplar milletvekillerine seçim bölgelerine gitmeden önce gönderilmek suretiyle sonuç hakkında şu cümlelerle bilgilendirilmişlerdir. "Bunlardan bir neticeye ulaşanlarını Sizce bilinmesini faydalı olduğumuzdan; seçim yerlerinize gitmek üzere olduğumuz şu günlerde şimdiye kadar aldığımız bir kısım cevapların suretlerini ilişik olarak sunuyorum.” (BCA 490.01.717.451.2./20.09.1950: 30).

\footnotetext{
1 Tek parti iktidarında farklı kategorilerde raporlar hazırlanmıștır. Bu raporlar kronolojik ve kategorik olarak șu bașlıklar altında toplanabilir: Şeyh Said Hadisesi ve sonrasında hazırlanan raporlar (1925-1927), Umumi Müfettişlerin hazırladıkları raporlar, tek parti hükümetlerinin üst düzey yöneticilerinin Vilayat-1 Şarkiye'ye yapmış oldukları geziler sonucu hazırladıkları "tetkik" raporları, CHP'de uzun bir süre Tunceli ve Bingöl milletvekilliği yapan Necmeddin Sahir Sılan tarafindan 1939-1951 yılları arasında hazırlanan raporlar ve CHP milletvekilleri tarafından çalışmamıza da konu olan "intihab/seçim bölgesi" ve "teftiș bölgesi" raporları. Detaylı bilgi için bkz. Ercan Çağlayan, Cumhuriyet'in Doğu'su: Devlet, Parti, Toplum, Pınar Yayınları, İstanbul 2019.

${ }^{2}$ Mehmet Kâzım Berker (D: İstanbul 1887-Ö:19 Temmuz 1961), İstanbul Hukuk Mektebi ve Paris Hukuk Fakültesi mezunu. Çeşitli hukuk birimlerinde görev yaptıktan sonra VII. Dönem Urfa Milletvekili.

3 Mehmet Esat Tekeli (D: Samsun 1896-Ö:25 Kasım 1967). İstanbul Mülkiye Mektebi mezunudur. Milli Eğitim ve Maliye ile ilgili farkl birimlerde görev yaptıktan sonra Maliye Vekâleti Müsteșarlığı, Maliye Tetkik Heyeti Başkanlığı, Siyasal Bilgiler Okulu Bütçe ve Amme Kredisi Profesörlüğ̈̈, TBMM VII. ve VIII. Dönem Urfa Milletvekilliği yapmıştır.

${ }^{4}$ Suut Kemal Yetkin, (D: Urfa 1903-Ö:18 Nisan 1980) Akademisyen, edebiyatçı, denemeci. TBMM II. Dönem Urfa Milletvekili Şeyh Saffet Efendi'nin oğludur. İlköğrenimini İstanbul'da ve orta ile lise eğitimini Galatasaray Lisesi‘nde yapmıştır. Devlet bursu yarışmasını
}

Dile getirilen görüşlere baktığımızda ise yapılan işlerin takip edildiğini, sorunlar konusunda çözüm üretilmemişse sorgulama mekanizmasının devreye girdiğini görmekteyiz (BCA 490.01.717.451.2: 79). Ayrica tespit edilen sorunların giderip giderilmediğini anlamamız açısından da bu raporlar önemlidir. Bu geziler aynı zamanda yetkili birimler üzerinde bir denetleme mekanizması görevi de görmüştür.

Aynı klasör içerisinde Cumhuriyet Halk Partisi il teşkilatının 1 Haziran 1945 gününden 31 Aralık 1945 gününe kadarki durumunu gösterir birinci 6 aylık çalışma raporu bulunmaktadır. Parti Nizamnamesinin 84 maddesinin J fikrası Parti İdare Heyetlerinin 6 ayda bir Genel Sekreterliğe bu yönde bir bilgilendirmeyi zorunlu tutmuştur. Rapordaki bilgiler daha çok il teşkilatının yapısı, çalışmaları ve siyasi gelişmeleri ortaya koyacak olan sorulara verilen cevaplardan oluşmaktadır (BCA 490.01.717.451.2: 25/1).

Yine aynı klasördeki CHP milletvekilleri Atalay Akan (TBMM 2010: 889) ${ }^{5}$ ve Osman Ağan (TBMM 2010: 757) ${ }^{6}$ tarafindan düzenlenerek Cumhuriyet Halk Partisi Genel Sekreterliğine 25 Nisan 1947 tarihinde sunulan Raporda; Birecik'te yaşanılan olumsuzluklardan dolayı diğer Urfa milletvekilleri Razi Soyar ${ }^{7}$ (TBMM 2010: 506), Esat Tekeli, Vasfi Gerger (TBMM 2010: 506) ${ }^{8}$ ile birlikte Birecik'e gidip yaptıkları görüşme ve incelemelerin sonucunu içermektedir.

Hazırlanan ilk rapor Urfa ve ilçelerinin ihtiyaçlarına yönelik iken sonrasında düzenlenen raporlar çok partili hayatın da etkisi ile daha çok siyasi gelişmeleri kapsamaktadır. Ayrıca CHP içerisinde yaşanılan çekişmelerin etkisi çok partili hayat başlamadan önce dar bir alanla sınırlı iken farklı alternatiflerin ortaya çıkması ile birlikte daha etkili bir hal almış, parti gündemini ciddi manada meşgul etmiştir.

Kısaca her üç rapor 1944-1948 Urfa'sı hakkında bize detaylı bilgiler vermektedir:

\section{Adliye Teşkilatı ve Cezaevlerinin Durumu}

Urfa, Siverek, Bozova (Yaylak) adliye teşkilatında bina konusunda sorunlar bulunmaktadır. Urfa adliyesinin eski olmasına yönelik bir yıl önce dile getirilen sorunlara çözüm bulma adına yeni bir binanın belirli kısımları kiralanmıştır. Fakat yeni binadaki nem olayı yüzünden çalışan tüm görevliler mustariptir. Urfa genelinde adliye kadrolarında da sıkıntı söz konusudur (Bayar, 2006: 64)9 ${ }^{9}$. Hilvan Adliyesi

kazanıp Fransa Sorbon Üniversitesinde Felsefe eğitimi görmüştür. 1934'te kurulmakta olan Ankara Üniversitesi Dil ve Tarih-Coğrafya Fakültesi'ne Estetik ve Sanat Tarihi doçenti olarak tayin edildi. TBMM VII. ve VIII. Dönem CHP Urfa Milletvekilliği yaptı. 1959-1963 yılları arasında Ankara Üniversitesi Rektörlüğü, iki kez Ankara Üniversitesi İlahiyat Fakültesi dekanlığı gibi farklı tarihlerde farklı üniversitelerde idarecilik yapmıştır.

${ }^{5}$ Hacı Atalay Akan, (D: Birecik 1913-Ö:1967) İstanbul Üniversitesi Hukuk Fakültesini bitirdi. Fransa Toulouse Hukuk Fakültesi Doktora yaptı. Hukuk ile ilgili çeşitli kademelerde görev aldı. VIII, XI, XII ve XIII Dönem Urfa Milletvekili.

${ }^{6}$ Osman Ağan, (D: Urfa 1903-Ö:1985) Ortaokul Mezunu, Urfa Ticaret ve Sanayi Odası Başkanlığı, CHP İl Başkanlığı. VIII, XI ve XII Dönem Urfa Milletvekili.

${ }^{7}$ Razi Soyar, (D; İzmir 1881-Ö:1949). İstanbul Yüksek Mühendis Okul mezunu. Demiryolları ile ilgili çeşitli birimlerde görev yaptı. VI, VII ve VIII Dönem Urfa milletvekili.

${ }^{8}$ Mustafa Vasfi Gerger, (D: Siverek 1904-Ö:1995). Ankara Adliye Hukuk Mektebi mezunu. VIII. Dönem Urfa milletvekili.

9 İktisat Vekili Celâl Bayar'ın hazırlayıp Aralık 1936 tarihinde Başvekil İsmet İnönü’ye verdiği Şark Raporunda da aynı yönde sıkıntılar dile getirilmiştir; "Hükümet binaları, bilhassa kazalardakiler, pek perişandır. Bu binalar içinde uzun müddet oturup çalıșanların, enerji ve muhakeme kabiliyetlerini kaybedeceklerinden korkulur. Yeni eleman, yeni bir 
diğer yerlerden farklı olarak yeni bir adliye binasına sahiptir. Fakat Bozova (Yaylak) kazasında olduğu gibi kadro yetersizliği söz konusudur. Kadro konusunda yaşanan sıkıntılar Viranşehir Adliyesinde had safhaya çıkmış ve acil olarak bir kâtibe ihtiyaç duyulmuştur. Çünkü Kâtibin yapması gereken işi hâkim ve savcılar yapmaktadır (BCA. 490.01.717.451.2: 77-78, 80).

Urfa cezaevinde haftanın 4 gününün mahkûmlara sıcak yemek verilmesi olumlu bir uygulama olarak ön plana çıkmıştır. Siverek Cezaevinde mahkûmlara günde 600 gr. ekmek verildiği, verilen ekmeğin yetersiz olduğu belirtilmiştir. Ekmeklerin gr. olarak düşüklüğü ve suyun tadının acı olması şikâyet konusudur.

Ayrıca kadın mahkûmlarının cezalarını çekmek için tutulan yerin sağlıklı olmaması, kapı girişi aralığında tutulmalarının mahzurları üstünde durularak çok hızlı bir şekilde kadınlar için ayrı bir yerin tahsis edilmesi istenmiştir. Bozova cezaevi ise kerpiçten inşa edilmiş olup, bir göz odadan oluşmaktadır. Özellikle kışın yağmurlu ve firtınalı havalarda mahkûmlar mağduriyet yaşadığından cezaevine uygun bir binanın tahsis edilmesi istenilmiştir.

Adliye teşkilatı ve cezaevlerine yönelik olarak Türkiye'nin birçok noktasında olan sorunun Urfa genelinde de yaşandığ görülmektedir. (TBMM Zabıt Ceridesi, Devre: II, Cilt: 31, İçtima Senesi: IV, 60; BCA. 490.01.717.451.2: 77-79).

$\mathrm{Bu}$ nedenle Harran'da bir sulh hâkimine ihtiyaç vardır. Hâkimsizlik bir önceki yıldan devam etmektedir. Bunun en büyük nedeni de kazada devlet görevlilerinin oturabilecekleri düzgün bir evin olmamasıdır. Adli davalar ancak $50 \mathrm{~km}$ uzakta bulunan Urfa'da görülmektedir. Bu durum maddi ve manevi olarak sikıntılara sebebiyet vermektedir (BCA. 490.01.717.451.2: 77-79). Bundan dolayı devlet görevlilerinin burada görev yapmasını sağlamak için barınma ihtiyaçlarının karşılanması haricinde düşünülen tedbirlerden bir tanesi de mecburi hizmet süresinin sınırlandırılmasıdır (BCA. 490.01.717.451.2: 84).

Sorunları aşma noktasında milletvekilleri tarafindan dile getirilen taleplerle ilgili olarak Adalet Bakanlığı 5 Haziran 1945 tarih ve 208 sayılı yazı, Maliye Bakanlığı ise 10 Mayıs 1945 tarih 30120/430 sayılı yazısı ile cevap vermiștir. Ancak Urfa ve kazalarının adliye binası, mefruşat, yazı makineleri ve kadro ile ilgili talepleri ödenek yetersizliği, mahalde uygun bina olmaması gibi nedenlerden dolayı olumlu cevap verilememiştir. Dile getirilen taleplerden bir kısmının sonraki yıllarda yapılacak planlama ile çözüme kavuşturulabileceği ve Siverek cezaevinde mahkûmlara verilen ekmek oranının 5 Eylül 1944 tarihinden itibaren 750 gr. çıkarıldığ 28,36).

\section{Bayındırlık}

Milletvekillerinin kalınacak yer konusundaki saptamalarına bakıldığında ilk değindikleri nokta devlet görevlilerinin

zihniyetle yerleşmeye çalıştı̆̆ımız bu muhitlerde muntazam hükümet dairelerinin, memur ailelerinin ikametgâhlarının inşası mühim bir mesele halindedir. Devlet otoritesinin kurulabilmesi için bu da bir zarurettir."

${ }^{10}$ Doğu ve Güneydoğu Anadolu Bölgesi genelinde var olan ev sorunun hiç olmazsa devlet görevlilerine yönelik çözüme kavuşturulması yönünde gayret gösterilecektir. "Doğu illerinde birinci derecede mahrumiyet bölgesi olarak tesbit edilen yerlerde memur evleri inşaına devam edilmektedir. Şimdiye kadar 158 ev yapılmıştır. 286 binanın inşaatı da önümüzdeki yıl bitirilecektir." Urfa, 6 Mayıs 1947. oturacak ev bulamadıklarından dolayı görev yerlerini terk etmekte olduklarıdır. "Bütün evler mahallî lehçeye göre kubbe tabir edilen topraktan inşa edilmiş mahruti şekillerden ibarettir. Bu şekillerden her biri bir oda veya binadan bir kısımdır ve birbirinden insan boyundan daha az irtifada bölmelerle ayrllmıştır. Altı toprak üstü toprak olan bu yerlerde" medeni bir yaşamın sürdürülebilmesinin mümkün olmadığı dile getirilmiştir. Bu olumsuzluktan dolayı gelen her görevli Hâkim birkaç gün görev yaptıktan sonra istifa ederek ayrılmıştır. Harran bağlamında dile getirilen bu sorun aslında neredeyse bütün Doğu ve Güneydoğu Anadolu Bölgesi'nin mustarip olduğu bir konudur. Bu soruna çözüm olarak da devlet memurlarının kullanımına verilmek üzere hükümet tarafından elverișli binaların inşa edilmesi ve görevlilerin belli bir ücret karşılığında burada oturmasının sağlanmasıdır (BCA. 490.01.717.451.2: 79) ${ }^{10}$.

Bir diğer sorun ise “...Idari manada düşünülen diğer bir tedbir sınır boyunca sırf Türk unsuru ile meskûn sağlam bir şerit meydana getirmektir. Ayrlca Urfa gibi yerlere sadece belirtilen vasıflarda memur göndermek yeterli olmadı̆̆l, görev yapacaklarl yerlerde hayat şartlarının mümkün mertebe Ankara, İstanbul, İmir gibi büyük merkezlerden geri olmayacak şekilde teşvik edici bir takım tedbirlerin alınması gerektiği dile getirilecektir. Bunun için barınmalarına uygun binalarl bulunmayan kazalarda mütevazı binalar yaptırmak ve bu binalardan memurları cüzi bir kira karşılı̆̆ında oturmalarının săglanmalıdır" 11 (BCA. 490.01.717.451.2: 84; TBMM Tutanak Dergisi, Dönem: VIII, Cilt 13,Toplantı: 3: 92) diye dile getirilmiştir. Bu konu ile ilgili olarak dönemin Adalet Bakanı Ali Rıza Türel hâkimler bağlamında dile getirilen devlet memurları için lojman yapılması konusunda sadece bir bakanlığın karar vermesinin söz konusu olmadığını, bu konunun bir hükümet işi, devlet politikası olduğunu vurgulamıştır (BCA. 490.01.717.451.2: 28).

\section{Toplumsal yapı}

Urfa'ya giden heyet tarafindan Urfa Valisi Hasip Kayhan'ın özel olarak topladığı bilgiler doğrultusunda vilayet nüfusunun mensup olduğu 1rkı ve bulundukları yerleri gösteren bir cetvel hazırlanmıştır. (Bkz. Tablo 1.)

Urfa Valisinin özel araştırmasına dayanılarak hazırlanan bu cetvelde Kürt ve Arap köyleri ile ilgili verilen veriler toplamda tutarken, Zaza, Türk ve Yezidi köylerinde verilen rakamlar ile toplamdaki sonuç birbirini tutmamaktadır.

Siverek'e bağlı Karacadağ nahiyesinde 4098 nüfus bulunup, halkının bir kısmı göçebe yaşam sürmektedir. Nahiyede Türkân, Keçan, Çemikân, Karakeçili, İzol aşiretleri bulunmaktadır. Bunlar Çeltik tarımı, koyunculuk, devecilik ve kervancılık işleri ile uğraşmaktadır. Nahiyede 53 köy bulunup, bazıları birleştirilmek suretiyle toplamda 14 muhtarlık vardır. Nahiye Müdürlüğü binası harap olup, ciddi manada tamire muhtaçtır. Binanın Diyarbakır-Siverek yolu gibi merkezi bir yerde olmasından dolayı görüntü ve

\footnotetext{
${ }^{11} \mathrm{Bu}$ konu sorun olarak kalmaya devam etmiş, meclis görüşmelerinde aralıklarla dile getirilmiştir. Erzurum Milletvekili GI. Vehbi Kocagüney, Doğu illerinin kalkınması için Hükümetçe hazırlanan plân hakkında yapılan görüşmelerde "Evsizlik, büyük bir buhran doğurmuştur, orada da karaborsa almış yürümüştür. Bu karaborsadan en çok sıkıntı çeken memurlardır. Bitlis'te, Van'da, Ağri'da, Erzurum'da, Elazığ'da ve Çoruh'ta memurlar evsizlik yüzünden büyük sıkıntı içindedirler. Hükümetin, bu illerin her birisine 15-20 ev yaptırarak memurları sıkıntıdan kurtarması lâzımdır" görüşünü dile getirecektir.
} 
hükümetin perestişi açısından nahoş bir durum arz etmektedir. Tüm uyarılara rağmen köylerdeki ölüm-doğum vakaları muhtarlar tarafından Nahiye Müdürlüklerine bildirilmemektedir. Bu da nüfusun gerçek durumunun tespit edilmesinde sorunlar ortaya çıartmıştır (BCA. 490.01.717.451.2: 80).

Tablo 1.

\begin{tabular}{lccccc}
\hline \multicolumn{1}{c}{ Yeri } & Kürt köyü & Arap Köyü & Zaza Köyü ${ }^{12}$ & Türk Köyü & Yezidi Köyü \\
\hline Urfa Mer. Kazas1 & 201 & 132 & 78 & 3 & - \\
\hline Siverek “ & 250 & 6 & - & - & - \\
\hline Hilvan “ & 138 & - & - & - & - \\
\hline Suruç & “ & 165 & - & - & - \\
\hline Birecik “ & 137 & 6 & - & 3 & - \\
\hline Bozova “ & 148 & - & - & - & - \\
\hline Harran “ & 25 & 184 & - & - & - \\
\hline Viranşehir “ & 168 & 46 & 24 & 48 & 11 \\
\hline \multicolumn{2}{r}{ Yekûn: } & 1232 & 374 & & 11 \\
\hline
\end{tabular}

Urfa merkez kazasının nüfusu : 30.000 olup 12.000’i

Türk’tür.

$\begin{array}{llllll}\text { Siverek } & \text { “ } & : 16.800 & \text { “ } & 2.000 \text { 'i } & \text { “ } \\ \text { Birecik } & \text { “ } & : 12.000 & \text { “ } & 7.000 \text { 'i } & \text { “ }\end{array}$

(BCA.490.01.717.451.2:82 BCA, 490.01.513.2060.3: 2; Gök, 2019: 290). ${ }^{13}$

Bölgede Türkan aşireti gibi kendilerinin Türk olduklarını söyleyen unsurlar bile Kürtçe konuşup Türkçe bilmemektedir. Siverek'e bağlı Çaylarbaşı bağlı bulunduğu kaza merkezine göre daha medenidir. Ancak burada yaşayan halk Kürt olmasına rağmen yüzde 75 'i Türkçe bilmektedir (BCA. 490.01.717.451.2: 80-81).

Hilvan kazasına bağlı Akziyaret nahiyesi 7753 nüfuslu olup, 53 köyü bulunmaktadır. Köyler birleştirme suretiyle 35 muhtarlık oluşturulmuştur. Nahiye merkez nüfusu 501 kişi olup tamamı Kürt'tür. Burada Türkçe konuşanların sayısı yok denecek kadar azdır. Fakat bu yerleşim yerlerinden farklı olarak Urfa merkez kazasına bağlı Kısas köyü ise bu bölgede “'Türklüğ̈̈n vasıfların'’ muhafaza etmesi ile dikkat çekmekte olup bu yönü ile diğer yerleşim birimlerinden ayrlmaktadır. Alevi mezhebinde olan bu köy halkı türlü türlü tesirlere boyun ĕgmeyerek benliğini ve dilini muhafaza etmiş bir Türk camiasıdır". Fakat ekonomik durum burada pek iç açıcı değildir. Halkı çiftçilikle uğraşmakta olup en az yarısı toprağının olmamasından şikâyetçidir. Yapılması gereken halkın toprak sahibi kılınması için tedbir alınmasıdır. Köylüler boş olan ve suyu bulunan Mecrahan köyünün kendilerine verilmesini istemişlerdir ( BCA. 490.01.717.451.2: 81).

Rakamlar diğer bazı sınır vilayetlerinde olduğu gibi Urfa vilayetinde de Türk unsurunun diğer unsurların ancak 'on altıda bir' oranında olduğunu göstermektedir. Diğer önemli bir nokta Urfa'da Türk dili Kürt vatandaşlarının yaşadıkları köylerde bilinmemesi ve Türkçe yerine Kürtçe konuşulmasıdır. Durumun bu şekilde devam etmesi halinde

\footnotetext{
12 Urfa'da günümüzde Zaza köyleri daha çok Siverek kazası sınırları içerisinde bulunmaktadır. Fakat raporda verilen bilgiler bunun aksinin göstermektedir.

${ }_{13}$ Burada verilen rakamsal bilgilerden farklı olarak Diyarbakır bölgesi müfettişi Hakkâri milletvekili Ali Reşat Göksidan tarafından Urfa vilayeti için hazırlanan 21 Şubat 1943 tarihli raporda ise “...Bunların içerisinde Birecik kazası tamamen karıșıksız Türk'tür. Siverek Türklüğün elinden kaçmış bir Türk aşiret camiasıdır" demektedir.
}

Kürt vatandaşlarını arzulandığı gibi milli davaya kazandırılamayacağı vurgulanmıştır 490.01.717.451.2: 82).

\section{Urfa'da Asayiş}

Urfa merkez kazasına bağlı Kısas köyünde muhtarlık seçimlerinden dolayı eski ve yeni muhtar arasında çekişme ortaya çıkmıştır. Yaşanılan bu olumsuzluklardan en fazla burada yaşayan halk etkilenmiştir. Bundan dolayı milletvekilleri telkinlerle, arabuluculukla birtakım nasihatlerde bulundukları gibi konu ile alakalı olarak Vali ve Umumi Müfettişi de uyarmışlardır. $\mathrm{Bu}$ olay milletvekillerinin bir takım toplumsal olaylara müdahale ettiklerini göstermesi açısından önemlidir (BCA. 490.01.717.451.2: 81).

Viranşehir kaza Kaymakamı, Suriye arazisinde bulunan İbrahim Paşa oğullarının ve diğer aşiretlerin Viranşehir ve çevresinden çifte tırnaklı hayvanları gasp etmek için 50'şer kişilik silahlı ve atlı çeteler kurmak suretiyle saldıracakları yönünde istihbarat alındığını dile getirmiştir (bkz. TBMM Zabıt Ceridesi, Devre: III, Cilt:5, İçtima Senesi: II: 3.; Ayrica bkz. TBMM Zabit Ceridesi, Devre: II, Cilt: 31, İçtima Senesi: I: 58) ${ }^{14}$. Kaymakam yaşanılacak böyle bir olayda Viranşehir kazasında bulunan Jandarma kuvvetinin sayısal olarak az olmasından dolayı yetersiz kalacağı endişesindedir. Böyle bir olayın yaşanılması durumunda Hükümetinde otoritesinin de sarsılacağını düşündüğü için bu yöndeki bir olayın engellenmesi için Urfa veya Siverek kaza merkezlerinde bulunan süvari kıtasından hiç olmazsa bir bölüğün Viranşehir'e gönderilmesini istemiştir. 19441945 tarihinde Suriye kaynaklı asayişe yönelik bu olayın gerçekleşebilme ihtimali güvenlik açısından bir zafiyetin olduğunu göstermektedir. Ayrıca Viranşehir cezaevinde 6 mahkûm, 15 tutuklunun çoğunluğu kaçakçılık suçu işlemiştir. Buradaki görevliler bu konuda da ortak bir irade ile kazadaki jandarma kadrosunun yetersizliğini dile getirerek bu durumun suç işlemeye meyilli olan kesimleri

\footnotetext{
${ }^{14}$ Cumhuriyetin ilk dönemlerinden itibaren sınır güvenliği sorun teşkil edecektir. Konu Atatürk'ün meclis açılıs konușmasında dile getirilecek kadar önemlidir: "Muallak meselelerimiz; biri Suriye hududunda bir türlü teessüs edemeyen emniyetin tesisi, diğeri mübadil, gayr mübadil vatandaşların hukuku temin edebilecek tesviyelerin 'bulunmasıdır. Senelerden beri birçok itilâflara ve imzalara iktiran etmiş olan bu meselelerin amelî hakiki radikal hallere rapt olunabilmesinden cidden memnun olacă̆ız."
} 
teşvik ettiğini belirtmişlerdir (BCA. 490.01.717.451.2: 80$81)$.

\section{Urfa Genelinde Kullanılan İletişim Dili}

Kürt vatandaşların genel itibariyle "sağlam, verdiği sözü tutan" insanlar olarak tanınsa da büyük bir çoğunluğunun Türkçeyi bilmemesinin onlar için büyük bir eksiklik teşkil ettiği vurgulanmıştır. Büyük devletlerin Sömürgelerinde bile kendi dillerini öğretmek ve bu yol ile yönetimleri altında yaşayan milletleri temsil ${ }^{15}$ için hiçbir fedakârlıktan çekinmemekte iken Urfa gibi Türk devletinin aziz bir parçasında yaşayan tüm halkın alınacak tedbirlerle Türk dili ile konuşmaları, Türkçe okuyup yazmayı öğrenmelerinin sağlanması gerekmektedir. Ancak o zaman temsil yolunda çok esaslı adımlar atılmış olunacaktır. Askere gidip gelen Kürt gençleri Türkçe öğrenmekte fakat bir süre sonra yaşadıkları ortama tekrar adapte olduklarından Türkçeyi unutmaktadırlar. $\mathrm{Bu}$ duruma karşı başvurulacak en etkili tedbirlerden bir tanesi Milli Eğitimin esaslı bir şekilde işe müdahale etmesidir. İnsanları birbirine sımsıkı bağlayan dil birliği, kültür birliğidir. Bu konu çok önemli olup derhal ele alınması gereken bir memleket meselesidir. Bakanlığın yapması gereken şey bu durumda bulunan yerleri derhal tespit etmek, köylerin birbirine yakınlıkları, ilişkileri göz önünde tutularak birkaç köy için merkezi vaziyette birer ilkokul açmasıdır. Açılacak bu okullara gönderilecek öğretmenlerin seçiminde de hassas davranılmalı ve mutlaka aslen Türk olmalarına dikkat edilmelidir (BCA, 490.01.513.2060.3: 4) ${ }^{16}$. Alınacak diğer bir tedbir buralarda görev yapan küçük büyük tüm memurların sağlam karakterli, çalışkan, bilgili, milli duygusu sağlam olanlarından seçilmesidir. Zira halkı hükümete yaklaştırıp uzaklaştıracak olanlar devlet görevlileridir. Yine bu alanda Halkevleri ve Halkodaları özellikle de Köycülük, Sosyal Yardım, Propaganda kolları faaliyetleri ile hükümetin işini kolaylaştıracağı dile getirilmiştir (BCA. 490.01.717.451.2: 82-83).

\footnotetext{
${ }^{15}$ Kendine mâl etmek, kendi içinde eritmek, asimilasyon.

${ }^{16} \mathrm{Bu}$ yönde yapılan tavsiyeler Ali Reşat Göksidan tarafindan da hazırlanan raporda da dile getirilmiştir. "Urfa şehir merkezinde ve kazalarının ve köylerinin heyeti umumiyesinde mevcut mekteplerin muallimlerini çok sıkı bir itina ile garp vilâyetlerimizden Türk çocuklarından seçmenin bir zaruret olduğuna sureti katiyede kanaat getirmiş haldeyim. Urfa'y cenuptan çevrelenmiş Arap ve Kürtler ile şimalden çevrelenmiş çeşitli unvanlarla köylere bölünmüş ve fakat tamamen Kürtçe konuşan yüzlerce köyü zapt edebilmek ve milli camiamızın içinde güvenilir bir kuvvet unsuru olarak tutabilmemiz için Urfa velayetine ve diğer müfettişliğime dâhil üç vilayette yatıll, ilk mektepler açmanın mutlak bir ihtiyaç olduğu benim anlayışımda silinmez yer etmiştir."

${ }^{17}$ Sitma: Dişi anofel cinsi sivrisineklerde bulunan parazitlerin, insanları 1sırmasıyla meydana gelen, nöbetler halinde ateș ve titremeye neden olan, yaygın bulaşıcı bir hastalıktır. Sıtmanın bir diğer adı malaryadır. Bkz. Erdem Aydın, Türkiye'de Sitma Savaşı, Türk Tabipler Birliği, Ankara 1998.

${ }^{18}$ Trahom: Göz kapaklarının içini döşeyen zarın üzerinde ilkin başlayıp tedavi edilmemesi durumunda gözün körlüğüne bile sebep olabilen bulaşıcı bir hastalık. Bkz. Sevilay Özer, "Türkiye'de Trahomla Mücadele; Türkiye'de 1927 sayımına göre 15.322'si erkek, 11.638'i kadın olmak üzere toplam 26.960 kör tespit edilmiştir. Türkiye'deki mevcut körlerin genel nüfusa oranı on bin de 19,7 'dir. Körlük vakasının en çok görüldüğü iller Gaziantep, Urfa, Mardin, Diyarbakır, Malatya gibi Güney ve Güneydoğu Anadolu'daki iller olduğu tespit edilmiştir. Bu dönemde körlüğün en önemli nedeni trahomdur.

${ }^{19}$ Dönemin sağlık bakanlığı kayıtları 1926-1950 yılları arasında sıtmadan muayene edilen kişilerin sayısını ve oranı şöyle vermektedir; “...İkinci Dünya Savașı'nın başlamasıyla sıtmalı sayısı tekrar yükselișe geçmiş, Savaş yıllarında ülkemizde saptanan sitmalı sayısında yaklaşık 3,5 kat
}

\section{Sağlık Alanında Yaşanılan Gelişmeler}

Cumhuriyetin ilk yıllarından itibaren Türkiye'nin birçok bölgesinde görülen sitma ${ }^{17}$, trahom (Özer, 2014: 121-152; Seren 1949:133) $)^{18}$ gibi hastalıklar en fazla Doğu ve Güneydoğu Anadolu bölgesinde etkisini göstermiş̧ir. II. Dünya Savaşı ve sonrasında içerisinde bulunulan olumsuz şartlarında etkisi ile Türkiye'de var olan bu salgın hastalıklar etkisini artırmıştır (Aydın, 1998: 23) ${ }^{19}$. Bu salgın hastalıklardan en fazla etkilenen yerleşim yerlerinden bir tanesi de Urfa'dır (Işık, 9 Temmuz 1939) ${ }^{20}$. Sitmanın en yoğun rastlandığı yerler bir sınıflamaya tabi tutulmuş ve en fazla rastlandığı yerleşim yeri arasında İçel, Adana, Hatay, Maraş, Gaziantep, Malatya, Adıyaman, Urfa, Mardin, Diyarbakır, Siirt, Elazığ, Tunceli, Bingöl, Van, Hakkâri, Ağrı illeri yer almıştır (Işık, 9 Temmuz 1939; Aydın, 1998: 12).

Siverek, raporun hazırlandığı 1944'li yıllarda genelde trahom, sitma ve intani paraziter hastalıklardan mustariptir. Sıtma oldukça yayılmıştır. Kazaya sekiz aylık süre içerisinde 1 kilo kinin, 300 adet atabrine ve 500 adet plâzmokin gönderilmiştir. Trahom hastalığ $1 \% 75$ oranlarına çıkmış olup bu açıdan kazanın hastalıkla mücadelede merkez kabul edilen bölgelerden sayılması lazım geldiği ve çocuk ölümlerinin fazla olduğu vurgulanmıştır. Öncesinde Siverek'te trahomla mücadele hastanesi varken, gerekli tamiratın yapılmaması ve başka elverişli bir binanın bulunmaması yüzünden 1945 Mart'inda hastane Sağlık Bakanlığı tarafindan Birecik'e taşınarak Siverek'te trahom tedavisi için sadece bir doktor, sağlık görevlisi ve hademe bırakılmıştır. Fakat var olan trahom dispanseri hastalığın kazada yoğun olmasından dolayı ihtiyaca cevap verememiştir. Bina ihtiyacı kaymakamlık tarafından karşılanacak hastanenin tekrar burada faaliyete geçmesi istenmiştir. Ayrıca nüfusu 17 bine yakın olan Siverek'te ne eczane ve ne de eczacı bulunmaktadır. Hastalığın eksik olmadığı kazada bu ihtiyacın bir an önce giderilmesi Sağlık

artış görülmüştür. 1942 yllında incelenen kanlar arasında saptanan sitmalı hasta sayıs Cumhuriyet Tarihi'nin en yüksek rakamın vermektedir. Bu yll içerisinde yapılan tüm kan incelemelerinde ortaya çıkan sıtmalı oranı \% 32.13 'tür.

Söz konusu bu dönemde sitma hastalarının artış nedeni İkinci Dünya Savaşı'nın getirdiği olumsuz koşullardır. Savaş koşullarından kaynaklanan ve tüm dünyada olduğu gibi Türkiye'de de etkili olan olağanüstü durum sitmanın ülkemizde tekrar yayılmasına neden olmuştur. Sitma ilacı olan kininin teminindeki güçlük ve ülke içi nüfus hareketleri bu artışın görülen başlıca nedenleridir. Savaş sırasında ortaya çıkan yoksulluk, iş ve askeri gereklilik gibi nüfus hareketleri sitmanın ülke içerisinde bir yerden başka bir yere taşınma ve yaygınlaştırllmasını kolaylaştırmıştır. Bundan dolayı başta Ege ve Güney bölgeleri olmak üzere ülkenin değişik bölgelerine sitmanın yayıldı̆̆ görülmüştür. '”

20 "Bilindiği gibi Suriye ile sinırdaşız. Bu yüzden ilimiz iki büyük tehlike karşısında bulunmaktadır; Biri Kaçak diğeri hastalık.” Urfa, 7 Kasım 1947; O. Özsoy, Urfa'da Trahom hastanesinin kuruluş macerasını anlatırken Başbakan İsmet İnönü'nün 28 Eylül 1932 tarihinde geçekleştirdiği Urfa ziyaretinde hastalıklar konusunda vaziyeti bizzat yerinde teşhis etmesinden sonra müdahale etme ihtiyacını duyduğunu dile getirecektir; "Milli Şefimiz İsmet İnönü güzel Urfa'mızı şereflendirdikleri vakit buranın en mühim derdini isabetli görüş ve dürbün bakışlar ile teşhis etmiş yurda her an şifa dağıtan elini uzatarak bu derin yaramızı tedavi etmiştir. TRAHOM... bu müthiş afet salgın halinde her gün bir çok vatandaşıı gözlerini kör ediyordu. Bunun şiddetle önüne geçmek zamanı çoktan gelmiş ve hatta geçmişti bile. Değişmez Şef işte daha o zaman Urfanın yanık bağrına bu şifa yurdunu kurdu.", 
Bakanlığından talep edilmişti (BCA. 490.01.717.451.2: 8385; TBMM Tutanak Dergisi, Cilt 13. 87) $)^{21}$.

Hilvan, Urfa'da sıtma hastalığının en az olduğu kazadır. Urfa merkez kazasına bağlı Kısas köyü sıtma hastalığı açısında iç açıcı olamayan bir görüntü arz etmektedir. Bozova'da sıtma hastalığı çok fazla olmasına rağmen Hükümet doktorluğu iki yıldan beri boştur. Bu hastalık yüzünden çocuklar arasında ölüm vakaları artmıştır. 1943 yılında sıtma hastalığı yüzde 45 nispetinde olup kazaya 1 kilo kinin, 1100 adet atabrine gönderilmiştir. Bozova kaza merkezinde bir göz tedavi evi ve hastaların tedavisine bakan sağlık memuru bulunmaktadır. Trahom hastalığg \% 65 nispetindedir. Viranşehir kazası çevresinde sıtma hastalığı yaygın olup Kinin ve atabrine şiddetle ihtiyaç vardır. Trahom hastalığı \% 5-10 oranındadır (BCA. 490.01.717.451.2: 86; TBMM. Zabit Ceridesi, Devre: VII, Cilt: 10, İçtima:1: 217-243.) $)^{22}$.

Urfa merkez kazası ile ilgili bu bilgiler Memleket Hastanesi başhekimliğinden alınmıştır. Verilen bilgilerden verilen bütçenin yetersiz kaldığını, artırılması istenildiğini görmekteyiz.

1943 yılında ortalama olarak günlük 14 hasta yatırılmış olup toplamda 4329 hastanın günlük iaşesi verilmiştir. Sahip olunan 5500 liralık bütçe tüm hastane giderleri için yetersiz kalmış, Sağlık Bakanlığı'nın vermiş olduğu 5000 lira ile giderler karşılanmıştır (BCA. 490.01.717.451.2: 86-87).

1944 yılı için verilen 5500 lira bütçe ile ortalama günlük ancak 5 veya 6 hasta bakılabilecektir. Ayrıca hastanenin ihtiyaç duyduğu yıllık odun ihtiyacı için 7000 lira tahsisat lazım iken ancak 3000 liralık bir ödenek ayrılmış bununla da hasta yatırılması mümkün olmayacaktır. Hastanenin çatı kısmı tamamen hasarlı olup yağmur suları akmaktadır. Onarım için 5000 lira lazımken 500 liralık bir tahsisat konmuştur. Hastanede her yıl ortalama 60 cenaze gömülme işlemi için yıkanıp, kefenlenmektedir.

Ortalama 1000 liraya ihtiyaç varken ancak 300 lira tahsisat verilmiştir. Belediyeye su burcu, kırık camların takılması gibi farklı kalemlerdeki masraflar için konulan 400 lira tüm ihtiyaçları karşılamasının mümkün olmadığı en az 1000 liraya ihtiyaç olduğu belirtilmiştir. Kısaca 50 yataklı hastanenin işletilebilmesi ve faydalı olabilmesi için her türlü masraftan önce iaşe, aydınlatma, 1sıtma gibi pek zaruri olan ihtiyaçlarının karşılanması gerekmektedir. Sadece iaşe için en az 12 bin liraya ihtiyaç vardır. Sağlık için tüm kalemler de aktarılan kaynakların yetersiz kaldığ 1 vurgulanarak, ödeneğin arttırılması istenmiştir (BCA. 490.01.717.451.2: 87).

\footnotetext{
211948 yılında CHP hükümeti tarafından Doğu illerinin kalkınmasına yönelik hazırlanan programda bu konu "illerin muhtelif yerlerinde sağllk merkezleri açmak, seyyar hekimlikler ihdas etmek, eczane olmıyan yerlerde sabit ve seyyar hekimliklerde ilaç bulundurmak, sağlık merkezlerinde bölgenin genişliğine göre ebe bulundurmak" suretiyle çözülmeye çalışılacağı vurgulanmıştır.

22 Sağlık Bakanı H. Alataş 1944 yılı bütçe görüşmelerinde Türkiye genelinde bulaşıcı hastalıkların durumu ile ilgili olarak gelen soruları cevaplayıp, genel bir değerlendirme yapmıştır.

${ }^{23}$ Sağlık Bakanı Hulusi Alataş 1942 yılı bütçe görüșmelerinde konu ile ilgili olarak; "Urfa, Adlyaman, Gazianteb, Malatya, Nizip, Seyhan'da 13 köyde tedavi merkezi açmak suretiyle trahom mücadelemizi tevsi etmek yolundaylz. Defaten her yerdeki ihtivaca cevap verebilmek için para bulmak kâfi değildir. Şahısları da beraber bulmak lâzımdır. Ancak bu
}

Sağlık Bakanlığı ile ilgili dile getirilen tüm bu taleplere Sağlık ve Sosyal Yardım Bakanı Dr. Sadi Konuk 24 Nisan 1945 tarih ve 159 sayılı yazıyla cevap vermiştir;

a) Sitma: 4707 numaralı Olağanüstü Sitma Savaşı Kanunu gereğince Urfa'nın bütün kazalarına sıtma teşkilatı yayılmıştır. Tabip ve sağlık kurucu kadrolarının çok kısa zamanda tamamlanması ile tam faaliyete geçirilmesi bakanlıkça prensip olarak benimsenmiştir. Urfa vilayeti ve ilçelerine yeterli miktarda sıtma ilaçları gönderilmiş olup bundan sonra da her türlü ihtiyaçları karşılanacaktır.

b) Trahom: Trahom teşkilatının doktor kadrolarında eksiklik varsa da 1942 yılı mezunlarından kura çekerek trahoma düşen 2 Doktor İstanbul Gureba Hastanesi'nde kursa gönderilmiştir. Stajlarını tamamlar tamamlamaz hemen görev yerlerine gönderileceklerdir (bkz. TBMM Zabit Ceridesi, Dönem: VI, Cilt: 25, İçtima:3: 301) ${ }^{23}$.

c) Urfa memleket Hastanesi'ne ait olan ihtiyaçlar incelenmiştir. $\mathrm{Bu}$ masrafların bakanlık bütçesinden karşılanması ne maddi ne de hukuki açıdan mümkün değildir. Hususi İdarenin 1945 yedi aylık bütçesinde bu ihtiyaçları karşılayacak tedbirlerin alınması için Urfa Valiliğine yazı yazılmıştır.

d) Urfa'da açık olan hükümet tabiplikleri 1942 senesi mezunlarından yapılan tayinlerle doldurulmuştur.

e) Siverek'te eczane açmak için herhangi bir taliplinin olmadığ 1 , olduğunda da derhal izin verileceği belirtilecektir (BCA. 490.01.717.451.2: 40; TBMM. Zabit Ceridesi, Cilt: 10: 222,226$)^{24}$.

\section{Urfa Bölgesi Halkevi-Halkodalarının Faaliyetleri}

Türkiye genelinde bir eğitim ve kültür kurumu olarak kurulan Halkevleri ve Halkodaları Urfa ve ilçelerinde toplumsal yapıda arzulanan dönüșümü sağlaması için ilk olarak Urfa merkezinde 23 Şubat 1934 yılında açılmıştır (BCA, 490.01.513.2060.3: 3) ${ }^{25}$. Arkasından Birecik, Siverek, Suruç ve Viranşehir Halkevleri ile Akziyaret, Kısas, Sırın, Halfeti, Ağrıl, Cibin, Hobap, Tisha, Bozova (Yaylak), Bazik, Kanbavşar, Çarmelik, Yaslıca, Hilvan, Harran, Akçakale ve Ceylanpınar (Resülayn) Halkodaları faaliyete geçmiştir ( Pınar ve Özdurğun, 2016: 870,881) .

Urfa Halkevi ile ilgili olarak yapılan temsillerde sorun yaşanmıştır. Temsil kolunda sergilenecek eserlerde birçok bayana ihtiyaç duyulması sıkıntı çıkarmıştır. Bölgenin özelliği itibariyle temsiller de görev alacak bayan bulmada zorluk yaşanmıştır. Bundan dolayı da arzulanan faaliyetler gerçekleştirilememiştir. Urfa gibi yerlerde verilecek temsillerin oyuncu ve bayan sayısı az olan, muhitte ilgi uyandıracak konulardan seçilmesi istenmiştir (Yıldırım,

kadar vüsat verecek kadar şahıs yetiştirmiş bulunuyoruz ve bu tevsii yaptık. Yeni sene için de şahıslar yetiştireceğiz ve bütçe imkânlarını da bulursak, mücadeleyi daha genişleteceğiz. Maruzatım bundan ibarettir” bilgisini vermiştir.

${ }^{24}$ Kazalarda genel manada eksikliği hissedilmiştir. "Eczane açılması şekli bir kanunla tesbit edilmiștir. Dolaştığım kazalarda halkın dileklerinin en başında eczanesizlik gelir. Filvaki eczane açmak serbesttir ve bir takım merasime tâbidir. Fakat orada eczane açılamıyor. Bu hususta vâki müracaata da, belediye tahsisatını verdiği takdirde eczane açılabilir..."

${ }^{25}$ Diyarbakır bölgesi müfettişi Hakkâri milletvekili Ali Reşat Göksidan hazırladı̆̆ı raporda; "Urfa'ya göre bu şehri tatmin edebilecek kâfi vüsat ve teşkilatlı bir halkevi binası halen yok ise de rehberliğimizle yeniden yapılacak bir binanın daha fazla maddi ağırlıklarını yüklenmeğe Urfalılar pek çok isteklidirler" demiştir. 
2017: 441-444) Spor şubesi de beklenilen çalışmaları gerçekleştirememiştir. İlde iki göl (Yıldırım, 2017: 444) ${ }^{26}$ ve binicilik için güzel atlar olmasına rağmen bu alanlarda istenilen faaliyetler gerçekleşmemiştir. Spor faaliyeti denilince sadece koşu akla gelecek ve bu amaçla 2 km'lik koşular düzenlenecektir (BCA. 490.01.717.451.2: 88).

Siverek Halkevi Köycülük Şubesi bütçenin yetersizliği ve nakil araçlarının bulunmamasından dolayı arzu edilen faaliyetleri gerçekleştirememiştir. Fakat Sosyal Yardım Kolu başarılı çalışmalar yapmıştır. 1089 fakire 28 gün boyunca 300'er gram ekmek vermiştir. Ayrıca 161 fakire 314 kilo yiyecek dağıtılmıştır. 40 çocuk kısmen 44 çocuk tamamen giydirilmiştir. Şubattan nisan sonuna kadar 70 fakir ilkokul öğrencisine her gün sıcak öğle yemeği verilmiştir. Fakir halka ilaç dağıtılmış, biri Urfa'da orta mektepte diğeri Diyarbakır'da sanat Okulu'nda iki fakir talebenin bir yıllık masrafları karşılanmıştır. Ayrıca 4 doktorun yardımı ile açılan Halk Evi Polikliniği’nde 376 fakir tedavi edilmiştir. 291 kişinin ilacı da Sosyal Yardım Şubesince temin edilmiştir. Halkevi salonu sandalye olmadığından faaliyetler aksamakta gerekli olan 500 sandalye CHP Genel Sekreterliğinden istenmiştir (BCA. 490.01.717.451.2: 88).

Bozova halk odasında hiçbir faaliyet gerçekleştirilememiş, okuma odasında kitap dergi namına bir şey bulunmamıştır. İki aylık bir geçmişi olan Viranşehir Halkevinde de düzgün bir faaliyet yapılmamıştır (BCA. 490.01.717.451.2: 88-89).

Milletvekilleri tarafindan hazırlanan rapordaki bilgiler doğrultusunda Urfa Genelinde Halkevleri ve Halkodalarında istenilen faaliyetler gerçekleştirilemese de Siverek'teki Sosyal Yardım Şubesi çalışmaları ile ön plana çıkmaktadır.

\section{Eğitim ve Kültür Durumu}

Urfa merkez kazasındaki Erkek Sanat Okulu, Kız Sanat Enstitüsü inşaatının bir an önce başlanıp bitirilmesi gerekmektedir. Kız Enstitüsü öğretmenleri için $5 \mathrm{ev}$ yaptırılacaktır. Gerekli olan arsa karşıllıksız verilmiștir. İnşaat için gerekli olan ödenek istenilmiştir. Urfa'da 10 dershaneli bir ilkokul inşası için tahsisat temin edilmiş, inşaatın başlaması için bir plan gönderilmesi, sürecinin hızlandırılması gerekmektedir. 1944 yılında Malatya Akçadağ Köy Enstitüsünden mezun olarak Urfa'ya gelecek olan 19 öğretmen için gerekli olan ev, okul ve arazinin temini konusunda hiç bir şey yapılmamış, gerekli talimatın verilmesi gerekmektedir. Urfa'nın farklı kültür yapısından dolayı yatılı bir ilkokula ihtiyaç vardır. Urfa Kız Enstitüsü ve ortaokulda belli branşlarda öğretmen açı̆̆ 1 bulunmaktadır. Bu öğretmenlerin gönderilmesi talep edilecektir. Ayrıca Urfa'da "Halilürrahman" gölü kenarında

\footnotetext{
${ }^{26}$ Urfa biri Balıklı Göl (Halilürrahman) ve diğeri de Aynzeliha Gölü olmak üzere iki küçük yapay göle sahipti. Su sporu en çok Aynzeliha Gölünde yapilmakta idi.

${ }_{27}$ Halilürrahman Külliyesi’nin en gösterişli yapılarından biri Rıdvaniye Camii ile Rıdvaniye Medresesi'dir. Yıkılan hamamıyla birlikte başlı başına bir külliye niteliğinde olan bu yapı, Osmanlı Devleti'nin Rakka valisi Rıdvan Ahmed Paşa tarafından 1129 (1717) yılında yaptırılmıştır.

${ }^{28}$ Kazalarda ortaokul yetersizliği Türkiye genelinde yaşanmıştır. Ankara milletvekili Belkis Baykan; "Vekâletimizden ikinci bir temennim de; intihap dairem olan Ankara vilâyetinin 12 kazasindan hiç birinde orta mektep yoktur. Maarif Şûrasının tesbit ettiği $A$ ve $B$ serisinde olan kazalarımızda bile henüz açılamadı. Hattâ bu kazalar arasında binalarını, malzemesini de temin edenler mevcuttur. Vekâlete bunun için müracaat
}

bulunan ve büyük bir sanat değeri taşıyan Rıdvaniye camiinde (Doğan, 2014: 29-34) ${ }^{27}$ askerler tarafindan devam eden işgalinin son bulması istenmiştir (BCA. 490.01.717.451.2: 8).

Siverek'te ilkokulu bitiren öğrenciler ortaokul olmadığından dolayı eğitimine devam edebilmek için Antep veya Diyarbakır'a gitmektedir. Çoğu aile ekonomik durumunun elverişsizliği yüzünden bu masrafları karşılayamayacak, çocukların eğitimi yarım kalacaktır. 1941, 1942 ve 1943 yillarında ilkokulu bitirenlerin sayıs1 250'yi bulmuştur. Bunların az bir kısmı büyük fedakârlıklarla ortaokul eğitimine devam etmektedir. İlçede en az 150 öğrenci potansiyeli var olup bunlar için bir ortaokula ihtiyaç duyulmaktadır. Siverek halkı ortaokul için gerekli olan 25 bin lirayı vermeyi taahhüt etmiş, hatta söz verilen paranın 10 bin lirasını da bankaya yatırmıştır. Alt katı ilkokul üst katı ortaokul olacak şekilde hazırlanan okul planı da Urfa Maarif Müdürlüğü’ne gönderilmiş, inşaat için Vekâletin yapı işinde kullanılacak olan kireç, kum ve taşın temini ve malzemenin nakli hususunda gerekli yardımı yapması, bu işin takipçisi olması talep edilmiştir (BCA. 490.01.717.451.2: 90; TBMM Zabit Ceridesi, Cilt: 25: $311)^{28}$.

\section{Tarımsal Alanda Yaşanılan Gelişmeler}

Raporda Siverek'te tarım kesimi ile yapılan görüşmelerde eski tarım araçlarını yerine pulluk ve araba isteyip istemediği sorulacak fakat onlar yollar bozuk kaldıkça ürünün sevkinde sorun yaşayacaklarından pulluk kullanmak suretiyle mahsulü arttırmaya ve araba kullanmaya ihtiyaç olmadığını vurgulamışlardır. Hilvan kazası da çevresindeki toprağın yumuşak ve çatlayan türden olmasından dolayı arabanın burada saplanıp, işe yaramayacağı, bunun yerine ordudan ucuz bedelle at verilmesini isteyeceklerdir. Böylece pullukla tarım yapabileceklerdir. Makine olarak sadece savurucu istemişlerdir (BCA. 490.01.717.451.2: 90).

Hem Siverek hem Hilvan'da dile getirilen bu eksiklikler o dönemde tarımda makineleşmeye geçmek için alt yapının yeterli olmadığını göstermesi açısından önemlidir (Bayar, 1981:112) ${ }^{29}$.

Akçakale'de özellikle Ziraat Vekâlet'inin kurduğu kombinalar göze çarpmaktadır. 92.000 dekar buğday ve 51.000 dekarı arpa olmak üzere toplamda 143 bin dekar arazi ekilmiştir. Ekilen saha $40 \mathrm{~km}$ uzunluğunda 4 ile $8 \mathrm{~km}$ derinliğindedir. Tesiste 10 adet biçerdöver, 29 adet traktör, 37 adet traktör pulluğu, 34 adet mibzer, 22 adet diskaro (toprağı ikilemeğe mahsus alet) bulunmaktadır (BCA. 490.01.717.451.2: 91).

Raporda Toprak Mahsulleri Ofisinin satın alımlarında usandırıcı gecikmeler yaşandığı gibi bedellerinin de

ettiğim zaman vaziyeti hazıra dolayısiyle muallim bulmakta çektikleri müşülâttan bahis buyurdular."

29 İktisat Vekili Celâl Bayar hazırladığı Şark Raporunda nakliyat işleri konusunda aynı sıkıntıları dile getirmiştir: "Doğu illerimizin ekonomik bakımdan en büyük bir derdinin de, nakliyat meselesi olduğunu arz etmek isterim. Memleketin kıymetli bir köşesi, denilebilir ki, sırf munakalesizlik (ulaşımsızlık) yüzünden senenin büyük bir kısmında memleketin diğer parçaları ile münasebet tesisi edememektedir. Doğu illerimizin bu vaziyeti, memleketin diğer kısımlart ile olduğu kadar bizzat kendi bünyesi içinde de vardır. Bir taraftan ulaşımsızlık, diğer taraftan nüfus azlı̆̆l, ekonomik değişimin canlanmasina mani olmuştur. Muntazam ve devaml mal nakli imkânı da olmaz ve dolaysıyla üretim de, gelişemez. ...Şüphesiz ki ideal, emin ve aralıksız nakliyatın temini için muntazam şoselere ihtiyaç vardır." 
zamanında ödenmemesinden dolayı çiftçinin zarara uğratıldığı dile getirilip, Ticaret Vekâletinden duruma müdahale edilmesi istenmiştir. Ayrıca Ofisin satın aldığ malları muhafaza etmede sorunlar vardır; "Hilvan ilçe merkezinde bir cami vardır. $O$ da Ofisçe anbar ittihaz edilmiştir. Içcinde 98 ton arpa, mercimek ve buğday muhafaza edilmektedir. Bu zahirelere bit arız olmuş ve bu zahireler çürümüştür.” Ticaret Bakanlığı 4 Mayıs 1945 tarih ve 171 numaralı yazı ile Ofisin alım ve satış işlerinin günü gününe bitirilmesi esasına göre düzenlemekte olduğu ve ara sıra beklenmeyen nedenlerden dolayı ortaya çıkan gecikmelerin alınan tedbirle derhal giderildiği bildirilecektir (BCA. 490.01.717.451.2: 37, 92, 95).

Maliye Bakanlığının 10.5.1945 tarih 30120/430 sayılı yazısı ve Tarım Bakanlığı 10/12.5.1945 tarih 124 sayılı yazıları ile Urfa genelinde halkın ihtiyaç duyduğu toprakların bir an önce dağıtılması taleplerinin bazı yerlerin bir numaralı iskân bölgesi içerisinde olması ve bu yöndeki taleplerin ancak çıkacak olan kanunun yürürlüğe girmesinden sonra göz önünde tutulacağını belirtmiştir (bkz. BCA, 490.01.513.2060.3: 3-4; BCA. 490.01.717.451.2: 36).

Tarım Bakanlığı 10/12 Mayıs 1945 tarih ve 124 sayılı yazısında; Bozova ile Viranşehir ilçelerinde Ziraat Bankasının birer şubesinin açılmasına dair talebin bu kurumun "silahaltında bulunan memurlarımızın bıraktığg boşluk yüzünden bugünkü teşkilatımızı müşülat ile muhafaza edebilmekte ve Viranşehir'de yaptırdı̆̆ımız etüt neticesinde; muhitin zirai ve iktisadi durumunun burada bir ajansın faaliyetini idameyi mümkün kllacak yeterlilikte olmadığ $l$ anlaşılmasından" dolayı olumlu cevap verilemediği belirtilmiştir (BCA. 490.01.717.451.2: 34).

\section{Kaçakçılık}

Kaçakçılık; bir malın yasal olmayan yollarla, gizli bir şekilde ülkeye sokulması ya da ülkeden çıkarılmasıdır. Gümrük vergisinden kaçırmak, ihracat veya ithalat yasağına takılmamak için başvurulan bir yoldur (TBMM Zabıt Ceridesi, Devre: 4, Fevkalâde İçtima, Cilt: 3: 120, 122) ${ }^{30}$. Güneydoğu Anadolu bölgesin de de bu olay kendisini daha çok sınır kaçakçılığı şeklinde göstermektir. Urfa bölgesinde kaçakçılık daha çok Türkiye ile Suriye arasındaki sınır

\footnotetext{
30 Hükümet üyeleri meclis kürsüsünde sürekli olarak kaçakçılıktan kaynaklanan soruları cevaplamak zorunda kalmıștır.

${ }^{31}$ Kaçakçılık, Urfa ilinde Cumhuriyetin ilk dönemlerinden itibaren sorun olmaya devam etmistir. Yerel gazeteler bu konu ile ilgili olarak yazılar yazıp ilanlar vererek halk uyarılmaya çalışılmıştır. Örnek olarak Ali Riza Açanal, Kaçakçılık Haramdır, Urfa, 25 Kasım 1949; "Yurtdaș Kaçakçı Vatan Hainidir" seklinde ilanlar çıkmıștır.

${ }^{32}$ Urfa milletvekilleri tarafindan ortak hazırlanan raporda dile getirilen bu durum Kazım Berker tarafindan 1944 yılı Gümrük ve İnhisarlar Vekâleti bütçesi ile ilgili yapılan görüşmelerde meclis kürsüsünde de dile getirilmiştir. "Bir sualim var. Bu sene intihap dairemizde iyi bir tetkik seyahati yaptık. Bu vesile ile cenup hudutlarında hayvan kaçakçılığının devam etmekte olduğunu gördük. Diğer taraftan Urfa kaza merkezinde çay ve kahvenin kaçak olarak satılmakta olduğunu gördük. İnhisarlar Idaresinin serbest bir şekilde çay ve kahve satmak imkânını bulamadı̆̆ına göre bu kaçakçılığın nasıl olduğunu ve neye istinat ettiğini lütfen izah buyururlar mı?" sorusuna bakan Gümrük ve İnhisarlar Vekili Suat Hayri Ürgüplü “...Kahve ve çay mevzuuna gelince: Devlet varidatını temin eden inhisar maddeleri olması dolayısiyle fiyatlart her yerde müstakar tutmak zarureti vardır. Orada ayrn bir fiyat tatbik edersek oradaki mal kaçak olarak diğer istihlâk pazarlarına gelecek ve kaçakçıllı̆ı teşvik etmiş olacaktır. Bununla beraber Ticaret Vekâletiyle yaptı̆̆ımız temaslar neticesi olarak oranin muayyen yerlerinde pazarlar kurmak suretiyle bizden oraya giden ve oradan bize gelen mallar için pazarlarda gümrük resimlerini istifa ederek satmak yollarında çalışacağız, güç bir iştir."
}

hattında gerçekleşmiștir. (Urfa, 25 Kasım 1949; Yeniıșık, 29 Birinci Kânun 1936) $)^{31}$.

Raporda Urfa kaza merkezinde İnhisar malı kahve ve çay kullanılmadığı, tüketilen kahve ve çayın kaçak olduğu dile getirilmiştir. Kahvehane ve gazino gibi umumi yerlerde İnhisar malı kahve ve çayın kullanımının sağlanması için Urfa valisi haftalık tüketim miktarını belirleyerek bu gibi yerleri her hafta denetleyerek, belirlenen oran kadar çay ve kahve alımını mecbur tutmuştur. Gümrük ve İnhisarlar Vekâleti 24 Nisan 1945 tarih ve 11/415 sayı ile gönderdiği yazıda; Urfa'da aylık kahve tüketiminin 250-300 kilo ve çay tüketiminin ise 97,5 kilo kadar olduğunu belirtmiştir. Kahvehane, gazino ve benzeri işletmelerin belirlenen tüketim oranlarına göre çay ve kahve almalarının sağlanması durumunda kaçak kullanımın kısmen önüne geçileceği yönünde Urfa valiliğince alınmış olan tedbirlerin yerinde olduğu belirtilmiştir (TBMM Zabıt Ceridesi, Devre: VII, Cilt: 10, İçtima:1: 194; BCA. 490.01.717.451.2: 41, $92)^{32}$.

\section{Ulaşım}

Erzurum Milletvekili Gl. Vehbi Kocagüney tarafından 9 Mayıs 1949 tarihinde meclis kürsüsünde dile getirilen "Doğuda yolsuzluk acı bir şekilde devam ediyor, iktisadi durumumuzda bu yolsuzluk yüzünden kalkamıyor. Birçok illerimizde ilçeler illere bağlı değildir" (TBMM Tutanak Dergisi, Dönem: VIII, Cilt: 19, Toplantı:3: 2899) sözlerindeki durum Urfa ve ilçeleri içinde geçerlidir.

Urfa Milletvekilleri raporlarında Diyarbakır-Siverek, Siverek-Urfa şose yollarındaki tahribatın fazlalığından dolayı dört tekerlekli bir araçla seyahat etmenin imkânsız olduğunu belirtmişlerdir. Arazinin tamamen taşlık olması nedeni ile tarla yolundan da faydalanmanın mümkün olmamasından dolayı Nafiye (Bayındırlık) Vekâletince bu yolların bir an önce tamir edilmesi istenmiştir. Aynı yöndeki talepler diğer kazalar içinde dile getirilmiş Akçakale, Viranşehir ve Bozova'yı Urfa'ya bağlayacak şose yola ihtiyaç olduğu vurgulanmıştır (BCA. 490.01.717.451.2: 90, 95-96; Urfa, 4 Kasim 1947; TBMM Tutanak Dergisi, Cilt 13: 87; Urfa Postas1, 29 Nisan 1949; Urfa, 30 Nisan 1949) ${ }^{33}$.

\footnotetext{
33 Yol konusunda yaşanılan sıkıntıdan dolayı konu Urfa kamuoyu tarafından yakından takip edilmiştir. "Eski bayındırlık Bakanı C. Kerim Incedayının Urfamızı teşriflerinde halkevinde halkla yaptı̆̆ konușmada vaat ettiği ilimiz dahilinde yapılacak şoselerin, Bakanın vazifeden ayrılmış bulunması Dolayısılla geri kalacă̆ endişesi adeta hemşerilerimizi üzen bir hal almıșt. Halbuki bu gibi kararlar bir programdır. Bunu yapacak olan şahıs değil bakanlıktır. Nitekim iş katiyen Aksamamış Bilakis daha ehemmiyetle ele alınmıştır. İlkin 1948 bütçesine konan 300.000 liralık tahsisatla Urfa-Birecik ve ayrica 300.000 lira ile D. Bakir-Siverek aras şoselerinin devlet eli ile inşasına karar verilmiş ve yolların Daimi bakımı için de 92,000 bin lira ödenek ayrılmıştır. Iyi takdir olunur ki Yol Bakımı çok mühim bir iştir. Bununla temin edilmiş bulunması işin ehemmiyetle ele alındığını gösterir.

Bu ve bunu takip edecek kararlarla Urfamızın yol derdi kökünden halledilmis olacak ve ilimizin iktisadi, ticari Hatta kültürel durumu üzerinde esaslı kalkınmalar elde edilecektir." 1948 y1lında hükümetçe hazırlanan program ile "yaz, kıs geçilmeye müsait yol şebekesi tesis etmek ve suları islah eylemeyi" gündemine almıştır. $\mathrm{Bu}$ alanda yaşanılan sorunlara çözüm bulunmamasından dolayı sonraki tarihlerde de dile getirilmiştir. CHP Genel Başkan yardımcısı Hilmi Uran 29 Nisan Cuma günü Urfa'ya geldiğinde yerel basında “Urfa yolsuzdur(ilçelerin birçoğu ile irtibat yapamayacak durumdadır.)" ifadeleri ile dile getirilen talepler arasında yolların yetersizliği de yer almıştır.
} 
Ayrıca raporda Akçakale'de Urfa'ya demiryolu tren hattının uzatılması talep edilmiştir. Urfa ile Akçakale arasında ortalama $50 \mathrm{~km}$ fazla olan mesafede ulaşımı sağlayan şose yolun sürekli kullanıma elverişli olmamasından dolayı genellikle tarla yolları tercih edilmektedir. Fakat kışın ve yağışılı havalarda batak haline gelen tarla yolları ulaşımı mümkün kılmamaktadır. Bundan dolayı bir an önce şose yolun esaslı bir şekilde tamir edilmesi veyahut demiryolu hattının uzatılması istenmiştir (BCA. 490.01.717.451.2: 95).

Nafia Vekâleti 31 Mayıs 1945 tarih ve 604/57 34 sayılı yazı ile dünyanın içerisinde bulunduğu durum ve demiryolu malzemesinin sağlanmasında yaşanılan güçlüklerin ülkede büyük çaplı demiryolu yapılmasını mümkün kılmadığını vurgulayacaktır. Ayrıca daha gerekli olan ana hatlar bitirilmedikçe mevzii ve mahalli ehemmiyette olan UrfaAkçakale hattını yapımının mümkün olmadığı bildirilmiştir (BCA. 490.01.717.451.2: 31).

Ayrıca İl özel ödeneğinin azlığından dolayı Urfa-Bozova yolunun yeniden yaptırılmasının mümkün olmadığı, fakat bozuk yerlerin 1slahına çalışılacağı, Urfa-Siverek ve Siverek- Diyarbakır yolunun 1slahatının birinci derecede göz önünde tutulduğu ve batak yapan yerlerin ve bozuk kısımların her yıl ödenek oranında sslah edilmekte olduğu, (TBMM Tutanak Dergisi, Dönem: VIII, Cilt: 19, Toplant1:3: 288) ${ }^{34}$ Viranşehir yolu üzerindeki bozuk kısımların düzeltileceği belirtilmiştir (BCA. 490.01.717.451.2: 32/2).

Siverek kasabasının içme suyuna yönelik projenin hazırlanması işi İçişleri Bakanlığı Belediyeler Fen Kurulu Müdürlüğü tarafindan ihaleye çıkarılmıştır. $\mathrm{Bu}$ proje Bayındırlık ile Sağlık ve Sosyal Yardım Bakanlığı tarafindan onandıktan sonra Belediyeler Bankası'ndan alınacak kredi ile kasaba için fenni bir su tesisinin inşa edilmesine başlanacaktır. Hilvan kasabasında bir artezyen kuyusunun açılması isteği şehir, kasaba ve köyler için yeraltı suyu sağlanması amacıyla kullanılabilecek bir sondaj ekibinin bulunmaması nedeni ile yerine getirilmesinin mümkün olmadığı bildirilmiştir (BCA. 490.01.717.451.2: 30/1; Bkz. TBMM Tutanak Dergisi, Cilt 13: 89) $)^{35}$.

\section{3. İktisadi Yapı}

Önceden Urfa vilayetinde üretilen $\operatorname{Akdarın}^{36}$ mahalli ihtiyaçtan fazlası Filistin, Suriye ve İzmir'e gönderilirken, buna imkân olmaması yüzünden fazla olan ürün elde kalıp çürüyecektir. Raporda da yüzden fazla ürünün ofis tarafından satın alınması istenilmiştir (BCA. 490.01.717.451.2: 95).

El sanatlarında önemli bir merkez olan Urfa'da "Cülhacılık" yani bez dokumacılığı diğer el sanatlarına göre daha fazla gelişmiştir (Kılıç, 2017:1781-1794). 1000

\footnotetext{
${ }^{34}$ Bayındırlık Bakanı Şevket Adalan, 1949 yılı programına Nizip-BirecikUrfa, Urfa-Siverek-Diyarbakır yol yapımının alındığını söyleyecektir.

${ }^{35}$ Başbakan Hasan Saka tüm doğu bölgesinde bu alanda var olan sorunları çözüme kavuşturmak için 1949 yılı bütçesine önemli miktarda kaynak aktarımında bulunduğunu belirtmiştir."1949 Bütçesine teklif halinde koyduğumuz 10 milyon lira âdeta bir başlangıçtır. Ve hiç olmazsa önümüzdeki senelerde bu işlerin, ne olursa olsun, esaslı bir surette, işaret buyurdukları su ișine, köprülere, illerimizi birbirine bağllyan geçitlere, yollara bir an evvel başlamak ve bu seneyi boş geçirmemek için bu küçük para ile işe atılmaya karar verdik. Meselenin para bakımından portesinin ne olduğu, bilâhara arzedeceğimiz müfredatl programlarla ve teferruatlı planlarla meydana çıkacaktır."
}

adet dokuma tezgâhı var iken iplik verilmediğinde dolayı işleyebilen tezgâh sayısı 120'ye kadar düşmüştür. Urfa Dokumacılar Küçük Kooperatifi Müdürlügü tarafindan Urfa'ya yeterli miktarda iplik gönderilmesi istenilmiştir. Urfa piyasasında kalay, kanaviçe, çuval, makara ipliği bulunmayıp bunun için önceden de İktisat Vekâletine başvuru yapıldığı, bu konunun çözüme kavuşturulması istenmiştir. İktisat Vekâleti 15 Mayıs 1945 tarih ve 14/583sayılı yazısı ile 95 sayılı Koordinasyon Heyeti kararı gereğince yapılan iplik dağıtımından sadece bu kararın yayınlanma tarihi olan 15 Şubat 1941 'den önce meslek olarak faal oldukları tespit edilenler yararlanabilmektedir. İllerde yapılan tezgâh tespiti sırasında usulü dairesinde kayıt ve tespit ettirilmeyenler iplik dağıtım hakkından yararlanamamaktadır. Çünkü iplik üretim durumunun elvermemesinden dolayı yapılan tespitin dışında kalan tezgâhlara iplik verilmesi mümkün olmadığını belirtmiştir (BCA. 490.01.717.451.2: 33, 95-96; Y1ld1z, 1989: 399) ) $^{37}$.

Raporda Urfa üzüm bağları bakımından oldukça zengin bir merkez olduğundan bir içki fabrikası açılması ve üreticilerin elindeki fazla miktardaki üzümün İnhisarlar İdaresi tarafından satın alınması talep edilmiştir. Yine Siverek'te 3500 üzüm bağı var olup her y1l ortalama 20.000.000 kilo üzüm mahsulü alınmaktadır. Ürünün günden güne artmasından dolayı bir şarap fabrikası kurulması istenmiştir.

Gümrük ve Tekel Bakanı Suat Hayri Ürgüplü verdiği cevapta; 1945 yılında yeniden örnek şarap evi kurulacak yerler belirlenmiş ve buna göre hazırlıklara başlanmıştır. Bunların sayısının arttırılması, eleman ve malzeme teminindeki zorluklar yüzünden dile getirilen talebin yıl için gerçekleştirilmesinin imkânsızdır. Siverek’te örnek şarap evi açılması ancak 1946 yılında değerlendirmeye alınabilecektir. Ayrıca Urfa'da 1944 yılında bir tane örnek şarap evi kurulmuştur. Burada 1945 y1lında 50.000 litre şarap yapılacaktır. Tekel idaresinin halen işletmekte olduğu müskirat (alkollü içki) fabrikaları İnhisar İdaresinin satışlarını fazlasıyla karşılamakta olduğundan Urfa'da müskirat fabrikası açılmasına imkân olmadığı ve Urfa'da üreticinin elinde satılmamış üzüm kalmadığının mahallinden de bildirildiği vurgulanmıştır (BCA. 490.01.717.451.2.: 41, 93-94, 96).

Yine Raporda Bozova'ya Adana tütünü yerine Malatya'nın Adıyaman tütününden gönderilmesi istenmiştir. İnhisarlar Vekâleti 3 Mayıs 1945 tarihinde 11/415 sayılı yazıya ile Tekel idaresinin halen Adıyaman tütünü adı ile bir ürünü bulunmadığı bildirmiştir. Ancak bu bölge tütünlerini de içerisine alan Malatya fabrikası ürünlerinin adı geçen bölge halkının zevkine uygun geldiğinden bölgeye dâhil bulunan Siverek ilçesine de öteden beri Malatya üretimi mal gönderildiği belirtilmiştir (BCA. 490.01.717.451.2: 39, 97).

\footnotetext{
36 Buğdaygiller familyasından, tohumları buğday yerine kullanılabilen, kuraklığa dayanıklı, otsu bir bitki türü.

${ }^{37} \mathrm{Bu}$ dönemde dokuma sanayinde genel manada sıkıntı yaşanmıştır. "Dokuma sanayii bu dönemde 1939'dan 1945'e kadar ikinci Dünya Savaşının etkisiyle gelişememiş ve bir durgunluk dönemine girmiştir. Bu dönemde özellikle ithalatın kesilmesi üzerine gerek özel ve gerekse kamu sektöründe dokuma sanayiinde yer alan işletmelerin üretim kapasiteleri düşmüşü̈r. Hatta bu dönemde BBYSP'na göre kurulan tesisler iç tüketimi karşllayamamıştır. Bu sebepten dolayı 2 Ağustos 1945 tarihinde Bakanlar kurulunca kabul edilen "Ivedili 5 Ylllık Plan” gereğince pamuklu, yünlü, suni elyaf sanayi kollarının geliştirilmesi ve yaygınlaştırılması kararlaştırılmış, fakat bundan da istenilen sonuç elde edilememiştir. "
} 
Viranşehir ili için kazada çok miktarda cins at olmasına rağmen sahiplerine sicil cüzdanı verilmemesinden dolayı koşulara katılamadığı dile getirilerek bu sorunun çözülmesi istenmiştir. Tarım Bakanlığı ise bu konu ile ilgili 10/12 Mayıs 1945 tarih ve 124 sayılı yazısında; At yetiştirmesi bakımından ve bilhassa Arap atı yönünden üstün bir bölge olan Urfa ilinde her yıl bakanlıkça Aşım Durakları ${ }^{38}$ açılmakta, sergiler tertip edilip, salgın hastalıklarla devamlı olarak mücadele yapılmaktadır. Arap atlarının tescil işi ise bu bölgede Islahı Hayvanat Kanunu hükümleri kapsamında devam ettiği ve her yıl Urfa'da yüzlerce Arap atına pedigri (soyağac1) verildiği vurgulanacaktır (BCA. 490.01.717.451.2: 33, 35).

İktisat Vekâleti 15 Mayıs 1945 tarih ve 14/583 sayılı yazısı ile Urfa merkezi ile Siverek ilçesinin Pamuklu Mensucat kontenjanının artırılması ve Urfa'da yerli mallar pazarı mağazasının açılması talebini de cevaplandırmıştır. Pamuklu mensucat, il ve ilçelerin sahip olduğu nüfus yoğunluğuna göre kullanıma sunulmaktadır. Bu yüzden pamuklu mensucat kontenjanının arttırılması talebi üretim oranından dolayı mümkün değildir. Ayrıca Yerli Mallar Pazarları ve Müessesesince birçok ilde satış mağazası açılmış ve bu suretle tüketicilerin üretilen yerli mallardan daha kolay bir şekilde yararlanması sağlanmıştır. Ancak açılan mağazalar için gerekli olan tesis, idare masrafları ile burayı işletecek elemanların teminindeki zorluklardan dolayı mağazaların ilk etapta nüfusun fazla olduğu mahallerde açılmasına başlanmıştır. İmkânlar artıkça nüfusun daha az yoğun olduğu yerlerde de şube açılabileceği bildirilmiştir (BCA. 490.01.717.451.2: 33).

\section{CHP İ Teşkilat Yapısı ve Yaşanılan Siyasi Gelişmeler}

CHP il teşkilatının 1 Haziran 1945 gününden 31 Aralık 1945 gününe kadar ki durumunu gösteren birinci 6 aylık çalışma raporu aynı klasör içerisinde yer alıp, matbu bir evrak üzerindeki sorulara verilen cevaplardan oluşmaktadır. CHP Urfa İl Başkanı Osman Ağan tarafından 22 Mart 1946 tarih ve 69 sayılı yazı ile CHP Genel Sekreterliğine gönderilmiştir (BCA. 490.01.717.451.2: 25).

Raporda Urfa vilayeti CHP teşkilatında kayıtlı partililerin sayısı ve eğitim durumlarını gösteren bilgiler tablo (Bkz. Tablo 2.) halinde hazırlanmıştır (BCA. 490.01.717.451.2: 20/2).

Tablo 2: Eğitim Bilgileri

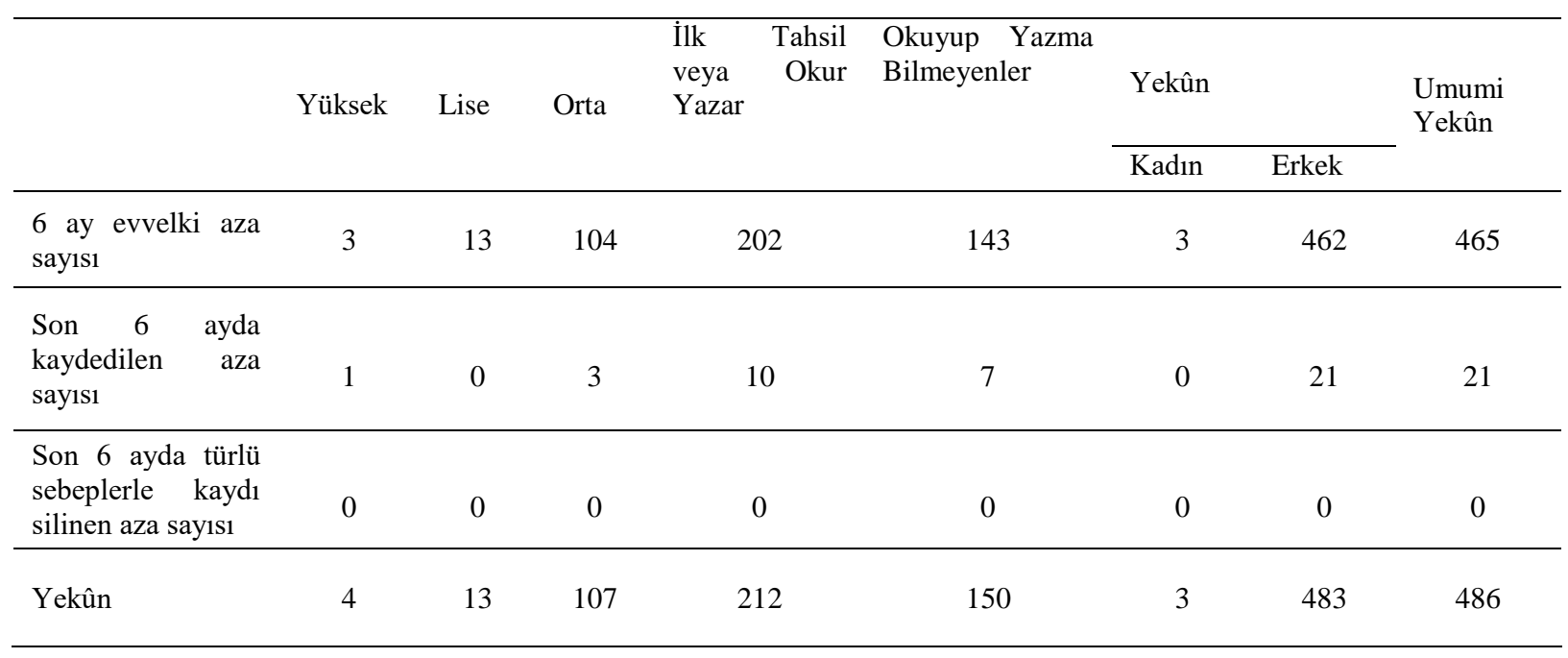

Urfa Vilayet İdare Heyeti Reis: Osman Ağan (Tüccarçiftçi), Muhasip: Mustafa Reşit Yetkin (Tüccar), Katip: Nurettin Nabi Akçan (Avukat) ile azalar Osman Abamaz (Fabrikatör), Ömer Alay (Belediye Reisi) Kasım Bimer (Çiftçi) ve Hasan Demirkol (Çiftçi)'dan oluşmaktadır. Halkevi Reisi ile birlikte kazaya ait İdare Heyeti azaları bulunmamaktadır. Urfa il merkezinde bir teşkilatlanma söz konusu olsa da Urfa vilayeti parti teşkilatı kademeleri ve buralarda kayıtlı aza sayısı tablosunda köy, mahalle, semt, nahiye ve kazalar ile ilgili herhangi bir bilginin verilmemesinden buralarda parti teşkilatının olmadığ anlaşılmaktadır (BCA. 490.01.717.451.2: 25/3-4; Akyol, 2006: 121$)^{39}$.

\footnotetext{
38 Aygır depoları ve aşım durakları ile devlet Arap atı soyunun yaygınlaşması için çalışmıştır. Aygır depoları ve aşım durakları atçılığın yanında eşek ve katır yetiştirilmesine de hizmet edecektir. Bkz. A Enver Akdoğan, At Yetiştiriciliğinde Aşım Durakları ve Faydaları, T.C. Trakya Umumi Müfettişliği Köy Bürosu Yay., İstanbul 1937.
}

Sorulan sorulara verilen cevaplarda; altı aylık süre içerisinde Vilayet Umumi Meclisi azaları arasında herhangi bir değişikliğin ve istifanın olmadığı, Parti ve hükümete halkı 1sındırmak ve prensiplerini benimsetmek amacı ile partililerle iki genel toplantı düzenlendiği ve burada ülke ile parti işleri üzerinde aydınlatıcı mahiyette iki konferans veriliği belirtilmiştir. Ayrıca partili üyelerce halka yönelik olarak parti prensipleri ve rejimin kökleşmesi için propaganda faaliyetlerinde bulunulmuştur (BCA. 490.01.717.451.2: 25/7-9, 10).

Parti mensuplarından nizamname gereğince aylık aidat alınmakta olup tahsilat oranı \% 87'dir. Verilen bilgilerden kayıtların muntazam bir şekilde tutulduğu, toplantıların

\footnotetext{
39 Mustafa Akyol tek parti iktidarında bölgesel bazda yapılan önemli hatalardan bir tanesinin CHP' sinin Doğu ve Güneydoğu Anadolu da yer alan birçok il merkezinde örgütünü kurmamış olması olduğunu savunmuştur.
} 
yapıldığı anlaşılmaktadır. İdare Heyeti üyelerin hepsi okuryazardır. Yapılacak herhangi bir seçimi partinin kazanmasına engelleyebilecek şahıs veya cereyanın ilde var olmadığı, Urfa'da muhalif bir parti henüz kurulmadığ 1 "ehemmiyetli cereyan göze çarpmakta ve bazı mektupların gelip gittiği haber alınmakta ise de” müteşebbis heyeti kurmak üzere kimsenin gelmediği ve sezilen hareketlerin dar bir alanla sınırlı olduğu vurgulanmıştır. İrticai fikirler besleyen kimse yoktur. Fakat Urfa Halkevi ve bazı halkodalarının çalışmasında "durgunluk ve ihmalkârlık" olduğu, bu yüzden de başkan ve komite başkanları arasında değişiklik yapılması düşünülmüştür (BCA. 490.01.717.451.2: 25/25).

1945 tarihinde resmi vilayet gazetesi olarak "Urfa", serbest gazete olarak da "Akgün" ve "Yenilik" çıkmaktadır. Partiden gazetelere para yardımı yapılmamaktadır. "Yenilik" gazetesi Neşriyat Müdürü Nuri Eralp haricinde yazı yazanların hepsi partide kayıtlıdır. Bunlardan "Yenilik" gazetesi Neşriyat Müdürü Nuri Eralp ve İdare Müdürü Celal Özbek' in durumları “şüphelidir”. Vilayette en çok "Urfa" gazetesi okunmaktadır (BCA.490.01.717.451.2: 25/7-9, 10).

Vilayet Merkezi'nde Kızılay, Çocuk Esirgeme, Yardım Sevenler ve Hava Kurumu şubeleri de vardır. Kısmen partilidirler. Kızılay Başkanı; Hüseyin Cindoğlu, Çocuk Esirgeme Başkanı: Müslüm Hayırlı, Yardım Sevenler Başkanı: Nedime Kamışlı, Hava Kurumu Başkanı: İhsan Özdemir'dir. Vilayette idari kadroyu oluşturanlarla herhangi bir anlaşmazlık bulunmamaktadır (BCA. 490.01.717.451.2: 25/26-27).

Raporda matbu olan soruların dışında Vilayet İdare Heyetinin düşünceleri kısmında; Urfa çevresi içinde kurulacak DP yetkili kurullarında görev alacak kişilerin isimlerinin telaffuz edildiği, İdare Heyeti üyelerinin kurulacak olan DP İdare Heyeti üyeleri üzerinde çalışarak oluşumu engelleme, yönetimlerine kendi adamlarını yerleştirmek suretiyle nüfuz etme yönünde bir takım faaliyetlerin içerisinde olacaklardır ${ }^{40}$. Ayrıca CHP'si örgütünün olmadığı ilçelerde açılması, hiç olmazsa nüfusu fazla olan Birecik, Siverek ve Suruç ilçelerinde açtırılmasının zaruri olduğu belirtilmiştir (BCA, 490.01.513.2060.3: 3; BCA. 490.01.717.451.2: 25/28-29; Urfa, 31 Mart 1945) $)^{41}$.

\section{Parti içi Çekişmeler}

Urfa'nın Birecik ilçesinde CHP içerisinde iç çekişme olarak ortaya çıkan olaylar, ülke genelinde çok partili siyasi hayata yeniden geçilmesi ile yaşanılan olaylara ayna tutması açısından önemlidir.

Cumhuriyet Halk Partisi milletvekilleri Atalay Akan, Osman Ăgan, tarafından düzenlenerek Cumhuriyet Halk Partisi Genel Sekreterliğine 25 Nisan 1947 tarihinde sunulan yazıda; Birecik'te yaşanılan olumsuzluklardan

\footnotetext{
${ }^{40}$ Urfa'da DP İl Başkanlığı 19 Haziran 1946 tarihinde açılacaktır.

${ }^{41}$ Urfa'da uzun bir süre CHP teşkilatı kurulmamıştır. Ancak çok sonraları açılmasına karar verilecektir. Diyarbakır bölgesi müfettişi Ali Reşat Göksidan hazırladığı raporunda; "Bölgeme dahil dört vilayet içinde parti teşkilatını derhal kurup pürüzsüzce çalıştırabilmenin yalnız Urfa vilayet merkezi ile Birecik kaza merkezinde mümkün olduğunu tasavvur ediyorum. Urfa ve Birecik'te Türk olan halkn hükümetle münasebeti korkuya müstenit değil bilerek, severek, anlayarak hükümeti ve yurdu benimsemeye
}

dolayı Urfa milletvekili Razi Soyar, Esat Tekeli, Vasfi Gerger ile birlikte Birecik'e geldiklerini, partideki durumu incelemek ve gerekli ise İlçe Kurulunu kuvvetlendirmek üzere yaptıkları görüşme ve incelemelerin sonucunda da: CHP ilçe İdare Kurul üyeleri arasında çıkan iç çekişmeler sonucu taraflardan birini teşkil eden Necip Deniz ve Suphi Sözmen ayrı liste ile belediye seçimlerine girmişlerdir. Seçim sonucunda başarılı olamayınca da parti içi muhalefete başlamışlar ve sonrasında Birecik'te DP'yi kurmuşlardır (BCA. 490.01.717.451.2:18/1; Özkan, 2013: 254-270 $)^{42}$. Yaşanan olumsuzluğu ortadan kaldırmak ve ilçedeki DP teşkilatının kapatılmasını sağlamak amacı ile milletvekilleri Vasfi Gerger ve Osman Ağan, Urfa Valisi Kâmuran Çuhruk, Birinci Genel Müfettiş Avni Doğan, Parti Bölge Müfettişi Hifzurrahman Öymen bir takım teşebbüslerde bulunsalar da olumlu bir netice elde edememişlerdir (BCA. 490.01.717.451.2: 19-2).

Raporda yaşanılan olumsuzlukların etkisi ile Birecik'te "Halk Partisi mensuplart ile Demokrat Parti mensuplarının hamamlarl, kahveleri, berberleri, hanları alışveriş yaptıkları dükkânlar bile ayrılmıştır. Particilik kadınlara ve mektep çocuklarına kadar bir aile kavgası şeklinde sirayet etmiş, hemen hemen tarafsız bir kimse kalmamış denilebilir" tespitini yaparak durumun günden güne kötüleştiğini vurgulamışlardır. Durumun bu noktaya gelmesinde ve Birecik'te arzulanan birlikteliğin sağlanamamasında Birecik Kaymakamı Melih Yuluğ'un

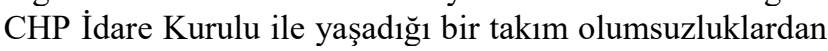
dolayı olaylarda olumsuz rol oynaması da etkili olduğu iddia edilmiştir.(BCA. 490.01.717.451.2: 20/3).

Aynı konu ile ilgili olarak CHP müfettişlerinden Turhan Cemal Beriker'in 16 May1s 1948 tarihinde Genel Sekreterliğe yazdığı yazı Birecik’te yaşananlar özelinde Türkiye demokrasisinin günümüzde bile yaşadığı sorunun nasıl bir bakış açısından kaynaklandığını ortaya koyması açısından önemlidir. Turhan Cemal Beriker, Osman Ağan ve arkadaşlarının raporu üzerinde yaptığ 1 inceleme neticesinde Birecik'te yaşanılan olayların yerel bir sorun olmadığı, ülkenin birçok yerinde aynı nedenlerden dolayı ortaya çıkan bir olumsuzluk olduğunu belirtecektir. Şöyle $\mathrm{ki}$;

"Çok partili rejime yeni girildiği sırada muhalefete geçmenin bir kısım partililer ve idareciler tarafindan adeta, kanun dişı bir hareket sayılarak telaşa düşülmesi. İdare amirlerinin, tarafsız kalarak anlaşmazlıklarl ortadan kaldıracaklarl yerde bu işlere müdahale ederek karşı partiyi ortadan kaldırmak ve güya hükümet partisini ayakta tutmak gayretkeşliği göstermeleri ve bunun doğurduğu aksu ameller. Nitekim Birecik'teki bazl hadiselerde, bu sakat zihniyetten doğmuştur: eski Kaymakam Melih YULUĞ, aynı zihniyetle vesayet rolünü üzerine alınca kasaba alt üst olmuştur. Muhtar seçiminde yaralama hadisesi zuhur etmiştir. İki parti veya zümre mensupları birbirine düşman kesilerek kahvelerini, hamamlarını ayırmışlardır."

matuftur." Verilen bu rapordan sonra Urfa merkezinde İl Başkanlığı açılmıştır. Bu tarihlerde Urfa kazalarından sadece Birecik'te CHP teşkilatı vardır. "Geçen Pazartesi günü Birecik ilçemiz giden Valimiz Feyyaz Bosut Bölge Müfettişimiz Konya Milletvekili Prof. Sadi Irmak ve Parti Başkanımız Osman Agan ilçede iki gün kalıp, İlçede CHP'si kurulması konusu üzerinde incelemeler yaptıktan sonra Urfa'ya dönmüşlerdir. "

${ }^{42}$ Birecik siyasetinde Kanlı, Sözmen ve Deniz aileleri etkili olup bunlar arasındaki mücadele ilçedeki siyasi gelişmeleri şekillendirmiştir. 
Bu durumu düzeltmek için Birecik’e giden milletvekilleri bunları anlaştırarak siyasi kuvveti halk partisinde toplamaya çalışmışlarsa da bir netice alamamıştır. "Bugünkü şartlar içinde Sun'i anlaştırma yollart takip ederek muhalefeti ortadan kaldırmaya çalışmanın hiçbir zaman müspet netice vereceğine kani değilim. Çok partili rejimin tabii icabl, muarız zümre veya partilerin seçim zamanlarında birbiriyle karşılaşmalarl, gösterecekleri gayrete göre halkın çoğunluğunu bir tarafin kazanmasıdır. Bu mevzuda aranacak şey bilvesile arz ettiğim gibi idare amirlerinin fuzuli müdahalelerde bulunmaktan vaz geçmeleridir. Böyle hareket edildiği takdirde halkl idare etmenin daha kolay olacaktır." (BCA. 490.01.717.451.2:16).

Nitekim kendisini halkın üstünde gören, "eser ve hareketlerinden bir Megaloman" olduğu Anlaşılan Kaymakam Melih Yulug'un yerine "ağırbaşlı" yeni bir Kaymakamın gelmesi ile olaylar yatışmış, iki parti arasında yumuşama artmıştır. "Bundan sonra idare amirleri büyük meclisin çıkarmakta olduğu seçim kanununu göz önünde tutarak, halkın kendi işini kendisine bırakırlarsa tedricen olgunluk artacak, bazı heyecanlı anlar zuhur etse bile seçim sonunda bulanık hava düzelecektir (BCA. 490.01.717.451.2: 17).

\section{Sonuç}

1944-1948 yılları arasında CHP Urfa milletvekilleri ve İl Yönetim Kurulunca düzenlenip gönderilen raporlarda verilen bilgiler; II. Dünya Savaşı sonrası Türkiye'yi etkisi altına alan olumsuz şartların özellikle iktisadi ve sağlık alanında Urfa'da da etkili olduğunu göstermektedir. Özellikle ulaşım gibi alanlarda Osmanlı Devleti'nden devir alınan olumsuz yapının fazla bir gelişme göstermeden devam etmiş olması sorunların boyutunu daha da artırmıştır.

Ayrıca tüm Türkiye'de Cumhuriyetle birlikte yaşanılan değişim, Urfa'nın sosyal yapısında sorunlar doğururken aynı zamanda da sahip olduğu toplumsal doku ile yeni yapının uyuşmasında fazla bir aşama kaydedilmemiştir. İkinci Dünya Savaşı sonrası siyasi hayatta meydana gelen değişim Urfa'da da hissedilmiş, çok partili siyasi hayata geçişin doğum sancıları şiddetli bir şekilde yaşanmıştır. Yönetim erkinin belirlenmesinde demokrasinin olmasa olmazı olan muhalefet olgusunun ortaya çıkmasına zihinlerin hazır olmaması yüzünden uygulamada sorunlar oraya çıkmıştır. Günümüz Urfa'sında incelediğimiz raporlarda dile getirilen sorunlar konusunda önemli gelişmeler yaşanmış olsa da hedeflenen düzeyde gelişmenin sağlanamadığı görülmektedir.

\section{Kaynakça}

\section{Arşiv Belgeleri}

BCA, 490.01.717.451.2/ 20. 09. 1950

BCA, 490.01.513.2060.3/ 02. 12. 1943

\section{Resmi Yayınlar}

TBMM Zabıt Ceridesi, Devre: II, Cilt:31, İçtima Senesi: IV, 11. 4. 1927. 1928 . 1931 .

Devre: IV, Cilt:3, Fevkalâde İçtima, 15. VII.

, Dönem: VI, Cilt: 25, İçtima: 3, 26. V. 1942.

, Devre: VII, Cilt:10, İçtima: I, 24. V. 1944.

TBMM Tutanak Dergisi, Dönem: VIII, Cilt 13, Toplantı: 3, 12. XI. 1948.

, Dönem: VIII, Cilt: 19, Toplantı: 3, 9.V.1949.

TBMM Albümü 1920-2010, I. Cilt: 1920-1950, (Editörler: Sema Yıldırım, Behçet Kemal Zeynel), TBMM Halkla İlişkiler Müdürlüğü Yay., Ankara, 2010,

II. Cilt: 1950-1980, (Editörler: Sema Yıldırım, Behçet Kemal Zeynel), TBMM Halkla İlişkiler Müdürlüğü Yay., Ankara, 2010.

\section{Gazeteler}

Işık

Urfa

Urfa Postas1

Yeniış1k

\section{Telif-Tetkik Eserler ve Makaleler}

Akdoğan, A. E. (1937). At Yetiştiriciliğinde Aşım Durakları ve Faydalarl, İstanbul: T.C. Trakya Umumi Müfettişliği Köy Bürosu Yay.

Akyol, M. (2006). Kürt Sorununu Yeniden Düşünmek, İstanbul: Doğan KİTAP

Aydın, E. (1998). Türkiye'de Sıtma Savaşı, Ankara: Türk Tabipler Birliği

Bayar, C. (2006). Şark Raporu, İstanbul: Kaynak Yayınları.

Çağlayan, E. (2019). Cumhuriyet'in Doğu'su: Devlet, Parti, Toplum, İstanbul: Pınar Yayınları

Çağatay, N. (1981). Ord. Prof. "Suut Kemal Yetkin (19031980)", Yıllık Araştırmalar, III, Ankara Üniversitesi İlahiyat Fakültesi Türk Ve İslam Sanatları Tarihi Enstitüsü, Ankara, ss. 5-7.

Doğan, Ş. (2014). "Şanlıurfa Rıdvaniye Camii, Medresesi ve Bazı İntibalar", ŞURKAV Şanlıurfa Kültür Sanat Tarih ve Turizm, ss. 29-34.

Gök, Selahaddin (2019), “Cumhuriyet Halk Partisi İktidarında Doğu ve Güneydoğu Anadolu'da İskân Politikalarl", İstanbul: Efe Akademi Yayınları

Kantemir, E. (1980). "Hocam Suut Kemal Yetkin”, Ankara Üniversitesi Eğitim Bilimleri Fakültesi, 13/1, ss. 407403.

Karatay, S. K. (2017). "Şanlıurfa Cülhacılığg ve Günümüzdeki Durumu” Ulakbilge, 5/17, ss. 17811794.

Özer, S. (2014). “Türkiye'de Trahomla Mücadele (19251945)", Ankara Üniversitesi Türk Inkllâp Tarihi Enstitüsü Atatürk Yolu, 54, ss. 121-152.

Özkan, A. (2013). “1947 Muhtarlık Seçimleri Bağlamında Urfa'da Parti Mücadeleleri (Vali ve Umumi 
Müfettişin Raporlarına Göre)", A.̈̈. Türkiyat Araştırmaları, 50, ss. 249-267.

Pınar, M. ve Özdurğun, Y. (2016). "Urfa Halkevi ve Faaliyetleri (1934-1951)" Uluslararast Sosyal Araştırmalar, 9/43, ss. 870-881.

Seren, S. (1949). “Türkiye'de Körlükler ve Körlük Sebepleri”, Săglık, XXIII/3, ss. 130-136.
Yıldırım, Y. (2017). 'Geleneksel Eğitim Sürecinde Urfa'da Çağdaş Bir Öğretmen: İhsan Özdemir (1926-1956)”, Ankara Üniversitesi Türk Inkllâp Tarihi Enstitüsü Atatürk Yolu, 61, ss. 437-466.

Yıldız, H. (1989). Türkiye'nin Sanayileşmesinde Dokuma Sanayiinin Yeri ve Önemi, İstanbul Üniversitesi Iktisat Fakültesi, 47/1-4, ss. 389-404. 